\title{
The role of parasitoid natural enemies in the success of introduced insects
}

\author{
by \\ Jane E. Allison, B.Sc. (Hons.)
}

A thesis submitted to the Faculty of Graduate Studies and Research in partial fulfillment of the requirements for the degree of

Master of Science

Department of Biology

Carleton University

Ottawa, ON, Canada

January 2009

(C) Jane Elizabeth Allison 2009 


\section{Abstract}

In this study, weed biocontrol agents are used as an example of introduced species, substituting the success of an agent for invasiveness, to test the hypothesis that highly successful introduced species more fully escape from natural enemies and have greater survival than their less successful counterparts. Field collected individuals from nine species of moth and beetle that vary in success were reared to determine levels of parasitism. We found support for the enemy release hypothesis for beetle species in that the most successful species experienced the lowest levels of parasitism. The most successful moth species experienced the higher parasitism levels than less successful species, contrary to expectation. Larval survival to adulthood was generally greater for all highly successful species. Our results demonstrate the need for comparisons involving the complete range of natural enemies, from predators to parasites, to identify which natural enemies limit introduced species populations and which native species are likely to switch to a novel host. 


\section{Acknowledgments}

I owe a great deal of thanks to Naomi Cappuccino, whose course on plantinsect interactions inspired me to start on this path. I have learned a great deal from Naomi, and she has always been there for me with advice, support and a good laugh when things don't go exactly as planned.

Locating the wide variety of species included in this study was facilitated by Stephen Darbyshire and Eric Snyder as well as members of the Bishops Mills Natural History centre's online NatureList. I would like to thank the many scientists at Agriculture Canada who gave of their time and expertise. I also give thanks to my committee members for all their helpful advice and suggestions.

The long process of collecting and rearing thousands of insect specimens was made easier by the help of Melaika Soule and my labmates Melody Jackson and David Carpenter. I'd especially like to thank Dave and Melody for disappearing into the field when the cops showed up, leaving me to explain the jar of insects all on my own.

Finally, I will be eternally grateful to my family and friends for putting up with me during this whole process and still being there at the end. 


\section{Table of contents}

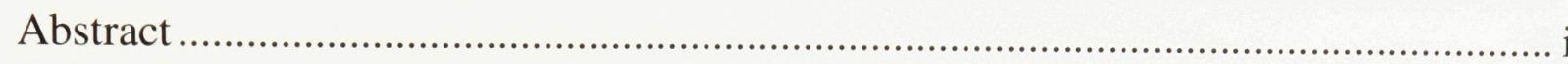

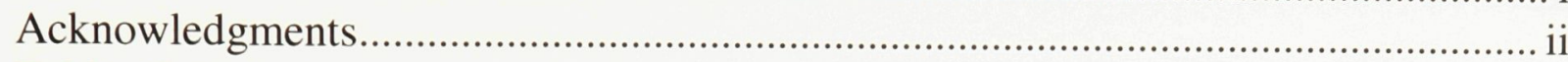

Table of contents ............................................................................................... ii

List of tables .................................................................................................... iv

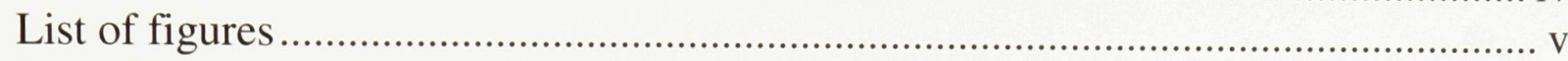

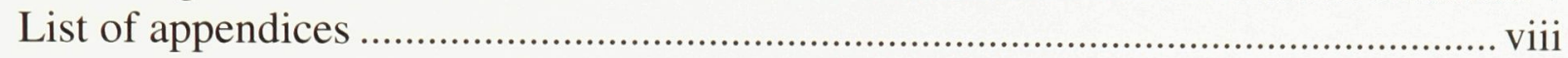

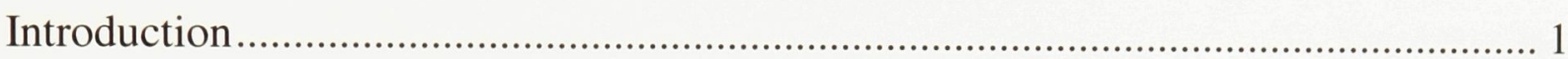

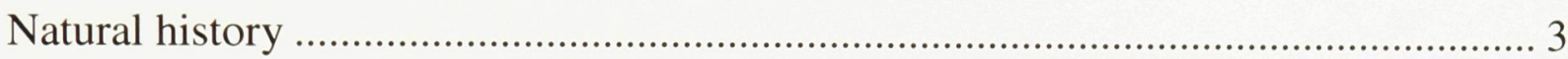

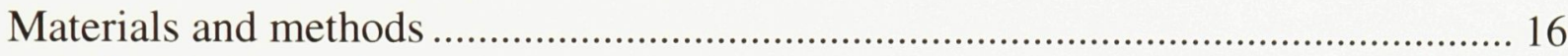

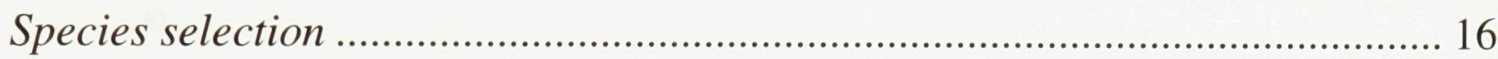

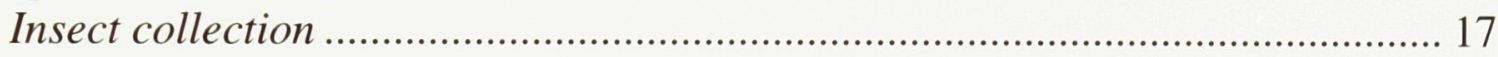

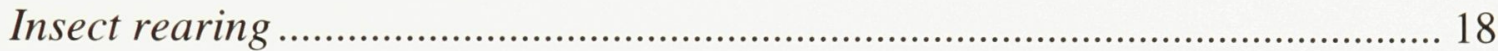

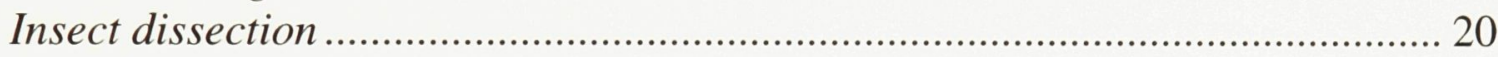

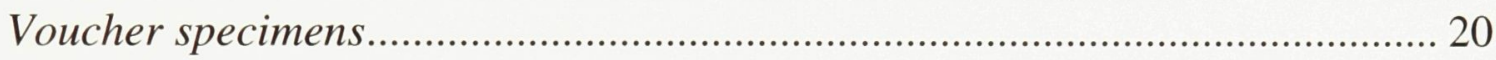

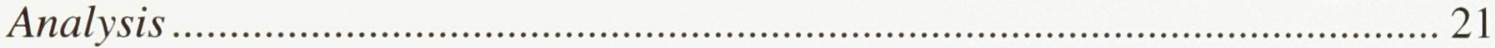

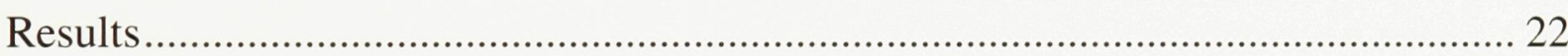

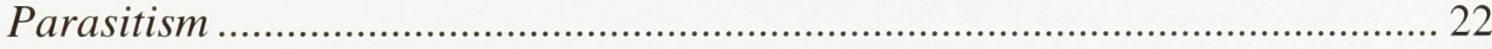

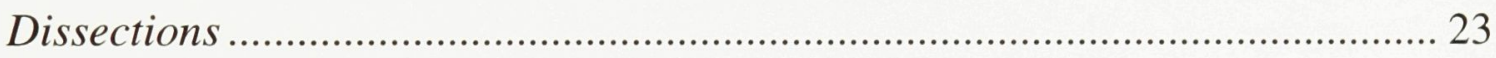

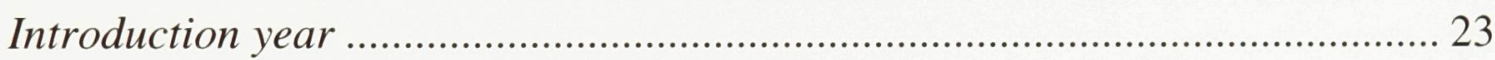

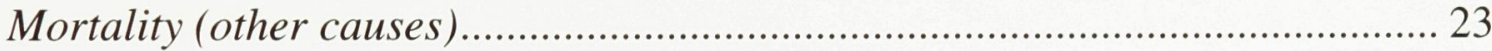

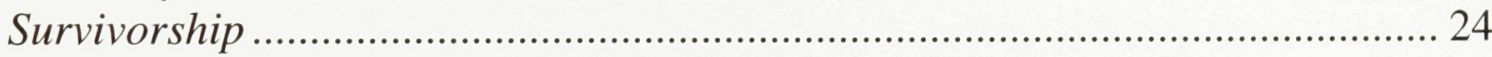

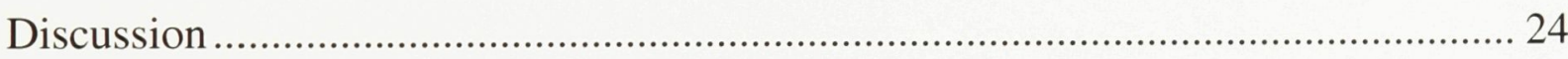

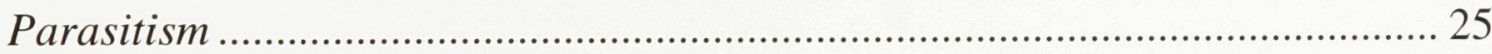

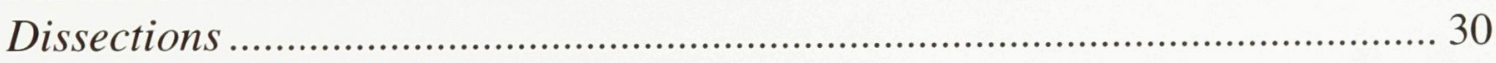

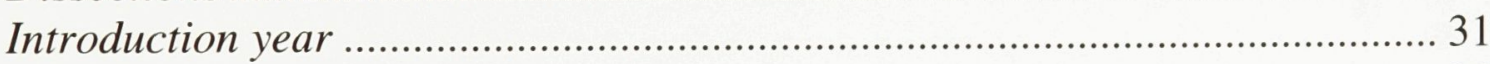

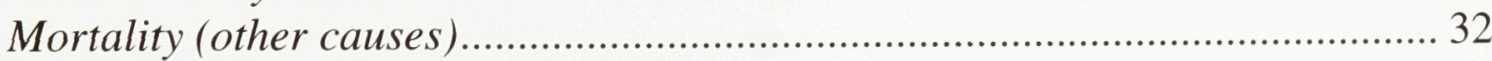

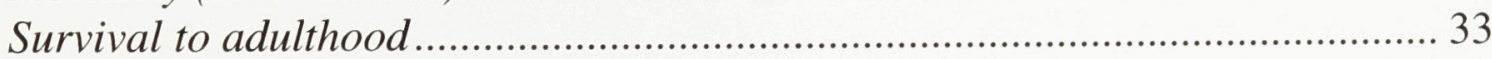

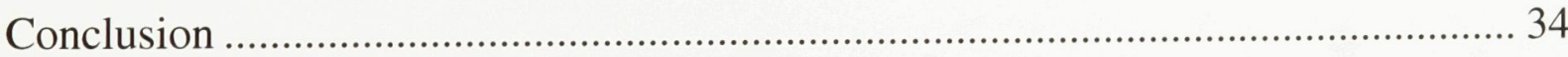

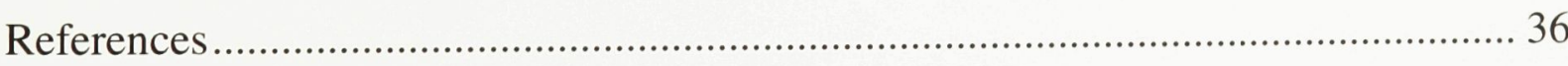

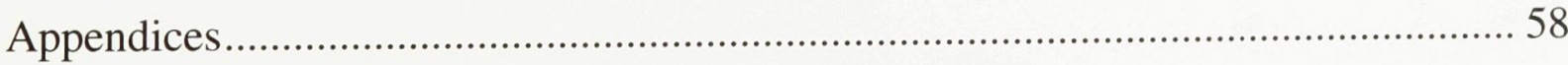




\section{List of tables}

Table 1. Success, taxonomy and host plant for herbivore species sampled in the 2007 and 2008 field seasons.

Table 2. Total individuals collected, parasitized and reared to adulthood for nine species of insect from field sites in 2007 and 2008. 59 


\section{List of figures}

Figure 1. Rearing process: (a) individual hydroponic arenas, (b) mass-rearing setup.

Figure 2. Mean proportion of parasitized larvae (mean \pm SE) for each of 9 species of insect collected in 2007. Sample sizes refer to the number of field collection sites for each species.

Figure 3. Mean proportion of parasitized larvae (mean \pm SE) for each of 9 species of insect collected in 2008. Sample sizes refer to the number of field collection sites for each species.

Figure 4. Mean proportion of parasitized larvae in 2007 and 2008 as a function of success as an introduced species (2007: $\mathrm{F}=0.21, \mathrm{P}=0.82 ; 2008$ : $\mathrm{F}=0.30, \mathrm{P}=0.75$ ). Species included (n): Galerucella spp., Chrysolina hyperici, Lobesia euphorbiana, Rhinocyllus conicus (Highly successful), Brachypterolus pulicarius, Calophasia lunula, Rhinusa antirrhini (Moderately successful), Cassida rubiginosa, Hyles euphorbiae (Unsuccessful).

Figure 5. Mean proportion of beetle larvae parasitized across field sites (n) in 2007 and 2008 (2007: $\chi 2=16.82, \mathrm{P}=0.00 ; 2008: \chi 2=8.35, \mathrm{P}=0.02$ ). Beetle species included: Galerucella spp., Chrysolina hyperici (Highly successful; 2007: $\mathrm{n}=9 ; 2008: \mathrm{n}=7$ ), Brachypterolus pulicarius (Moderately successful; 2007 \& 2008: n=3), Cassida rubiginosa (Unsuccessful; 2007: $\mathrm{n}=7 ; 2008$ : $\mathrm{n}=3$ ). Letters denote significantly different means according to Mann-Whitney pair-wise comparison.

Figure 6. Proportion of moth larvae parasitized (mean \pm SE) across field sites ( $\mathrm{n}$ ) in 2007 and 2008 (2007: $\mathrm{F}=6.09, \mathrm{P}=0.03 ; 2008: \mathrm{F}=1.07, \mathrm{P}=0.38$ ). Moth species included: Lobesia euphorbiana (Highly successful; 2007: $n=4 ; 2008$ : $n=6$ ), Calophasia lunula (Moderately successful; 2007: n=3; 2008: n=4), Hyles euphorbiae (Unsuccessful; 2007: $n=3 ; 2008: n=2$ ). Letters denote significantly different means (Tukey's HSD).

Figure 7. Proportion of weevil larvae parasitized (mean \pm SE) across field sites (n) in 2007 and 2008 (2007: $\mathrm{t}=-1.55, \mathrm{P}=0.18 ; 2008: \mathrm{t}=-1.96, \mathrm{P}=0.09$ ). Weevil species included: Rhinocyllus conicus (Highly successful; 2007: $\mathrm{n}=4$; 2008: $\mathrm{n}=5$ ), Rhinusa antirrhini (Moderately successful; 2007: $n=3 ; 2008$ : $n=4$ ).

Figure 8. Proportion of dissected weevil larvae parasitized (mean \pm SE) across field sites (n) in 2008 ( $\mathrm{t}=-3.71, \mathrm{P}=0.01)$. Weevil species included: Rhinocyllus conicus (Highly successful; 2007: $\mathrm{n}=4 ; 2008$ : $\mathrm{n}=5$ ), Rhinusa antirrhini (Moderately successful; 2007: $n=3 ; 2008: n=4)$.

Figure 9. Proportion of larvae parasitized as a function of introduction year (2007: Spearman's Rho=-0.44, $\mathrm{P}=0.01, \mathrm{n}=36 ;$ 2008: Spearman's Rho=-0.39, $\mathrm{P}=0.02, \mathrm{n}=34$ ). 
Species included: Galerucella spp., Chrysolina hyperici, Lobesia euphorbiana, Rhinocyllus conicus (Highly successful), Brachypterolus pulicarius, Rhinusa antirrhini, Calophasia lunula (Moderately successful), Cassida rubiginosa, Hyles euphorbiae (Unsuccessful).

Figure 10. Proportion of beetle larvae dead (causes other than parasitism) across field sites (n) in 2007 and 2008 (2007: $\chi 2=3.95, P=0.14 ; 2008: \chi 2=4.02, P=0.13)$. Beetle species included: Galerucella calmariensis, G. pusilla, Chrysolina hyperici (Highly successful; 2007: n=9; 2008: n=7), Brachypterolus pulicarius (Moderately successful; 2007 \& 2008: n=3), Cassida rubiginosa (Unsuccessful; 2007: $n=7 ; 2008: n=3$ ).

Letters denote significantly different means according to Mann-Whitney pair-wise comparison.

Figure 11. Proportion of moth larvae dead (causes other than parasitism) (mean \pm SE) across field sites (n) in 2007 and 2008 (2007: $\mathrm{F}=0.09, \mathrm{P}=0.92 ; 2008: \mathrm{F}=10.08$, $\mathrm{P}=0.01$ ). Moth species included: Lobesia euphorbiana (Highly successful; 2007: $\mathrm{n}=4$; 2008: $n=6$ ), Calophasia lunula (Moderately successful; 2007: $n=3 ; 2008: n=4)$, Hyles euphorbiae (Unsuccessful; 2007: n=3; 2008: n=2). Letters denote significantly different means (Tukey's HSD).

Figure 12. Proportion of weevil larvae dead (causes other than parasitism) (mean \pm SE) across field sites ( $\mathrm{n})$ in 2007 and 2008 (2007: $\mathrm{t}=-1.05, \mathrm{P}=0.34 ; 2008: \mathrm{t}=3.14$, $\mathrm{P}=0.02$ ). Weevil species included: Rhinocyllus conicus (Highly successful; 2007: $\mathrm{n}=4 ;$ 2008: $\mathrm{n=5}$ ), Rhinusa antirrhini (Moderately successful; 2007: $\mathrm{n=3;}$ 2008: $\mathrm{n=4}$ ).

Figure 13. Mean proportion of larvae surviving to adulthood in 2007 and 2008 as a function of success as an introduced species (2007: $\mathrm{F}=0.79, \mathrm{P}=0.50 ; 2008: \mathrm{F}=0.33$, $\mathrm{P}=0.73$ ). Species included (n): Galerucella spp., Chrysolina hyperici, Lobesia euphorbiana, Rhinocyllus conicus (Highly successful), Brachypterolus pulicarius, Calophasia lunula, Rhinusa antirrhini (Moderately successful), Cassida rubiginosa, Hyles euphorbiae (Unsuccessful).

Figure 14. Proportion of beetle larvae surviving to adulthood across field sites (n) in 2007 and 2008 (2007: $\chi 2=4.62, \mathrm{P}=0.09 ; 2008: \chi 2=6.86, \mathrm{P}=0.03)$. Beetle species included: Galerucella spp., Chrysolina hyperici (Highly successful; 2007: n=9; 2008: n=7), Brachypterolus pulicarius (Moderately successful; 2007 \& 2008: n=3), Cassida rubiginosa (Unsuccessful; 2007: $n=7 ; 2008: n=3$ ). Letters denote significantly different means according to Mann-Whitney pair-wise comparison.

Figure 15. Proportion of moth larvae surviving to adulthood (mean $\pm \mathrm{SE}$ ) across field sites $(\mathrm{n})$ in 2007 and 2008 (2007: $\mathrm{F}=0.86, \mathrm{P}=0.46 ; 2008: \mathrm{F}=6.46, \mathrm{P}=0.02)$. Moth species included: Lobesia euphorbiana (Highly successful; 2007: $n=4 ; 2008: n=6$ ), Calophasia lunula (Moderately successful; 2007: $n=3 ; 2008: n=4$ ), Hyles euphorbiae (Unsuccessful; 2007: $n=3 ; 2008: n=2)$. Letters denote significantly different means (Tukey's HSD). 
Figure 16. Proportion of weevil larvae surviving to adulthood (mean $\pm \mathrm{SE}$ ) across field sites in 2007 and 2008 (2007: $\mathrm{t}=2.26, \mathrm{P}=0.07 ; 2008$ : $\mathrm{t}=0.54, \mathrm{P}=0.61)$. Weevil species included: Rhinocyllus conicus (Highly successful; 2007: $n=4 ; 2008: n=5$ ), Rhinusa antirrhini (Moderately successful; 2007: $n=3 ; 2008$ : $n=4$ ). 


\section{List of appendices}

Appendix A. Larval collection data ................................................................ 59 


\section{Introduction}

Global movement of species into new geographic ranges can have negative consequences for invaded ecosystems. Only a fraction of introductions are thought to lead to successful establishment, but there is little evidence to support this conclusion (Ehler, 1998). Although they are often minor members of their native communities, some introduced species are capable of outcompeting residents in novel ranges, thereby becoming invasive (Callaway and Aschehoug, 2006). The factors that facilitate invasions are not well understood making it difficult to identify species that will persist in new environments (Shea and Chesson, 2002).

The enemy release hypothesis (ERH) is most often cited as the reason for the success of non-native species. According to this hypothesis, introduced species gain competitive advantages in new environments where natural enemies are absent or in low abundance (Keane and Crawley, 2002). If freed from natural enemies, introduced insects should establish large populations limited only by resource quality. Non-native insects may be able to out-perform native competitors if they suffer fewer natural enemy attacks in the introduced range. When applied to non-native plants, experimental results for the ERH have been mixed (Wolfe, 2002; Agrawal and Kotanen, 2003; Mitchell and Power, 2003; Agrawal et al., 2005; Cappuccino and Carpenter, 2005). Comparisons of introduced insects to native congeners and to conspecifics in their native range have failed to support the enemy release hypothesis (McEvoy, 2002; Colautti et al., 2004). However, comparisons that account for the impact of the introduced species are often overlooked in tests of the ERH (Colautti et al., 2004; Cappuccino and Carpenter, 2005). According to the enemy release 
hypothesis, highly invasive species should be free from natural enemies to a greater degree than their less successful counterparts. Additionally, survivorship to adulthood should be higher for invasive species than for non-invasive introduced species.

Biological control (hereafter biocontrol) programs are predicated on the assumptions of the enemy release hypothesis (Van Driesche and Bellows, 1996). Assuming that exotic plants are invasive because they have escaped from herbivory, specialist herbivores are imported to control invasive weed populations. In turn, weed biocontrol agents (herbivores) are assumed to have escaped their own coevolved natural enemies upon introduction, allowing them to reach high population densities and provide greater control of the target weed. Establishment of biocontrol agents is estimated to be over $60 \%$, however, most biocontrol agents fail to suppress the target weed and this often attributed to the effect of natural enemies (McEvoy, 2002).

Intentionally introduced biocontrol agents provide a unique opportunity to study the relationships between introduced insects and natural enemies. Information concerning release, establishment and impact on the target weed is available for these species. The success of a biocontrol agent can be used as a surrogate for invasiveness.

In this study, we use weed biocontrol agents as an example of introduced species to test the enemy release hypothesis. Specifically, nine species of established biocontrol agent of varying success are used to compare levels of parasitism and survival to adulthood. We hypothesize that successful introduced species will more 
fully escape from parasitoid natural enemies than do their less successful

counterparts. We also predict that mortality (exclusive of parasitism) will be higher for unsuccessful introduced species than for highly successful introduced species.

Lastly, we hypothesize that survival to adulthood will be higher for successful introduced species than for unsuccessful introduced species.

\section{Natural history}

The nine biocontrol agents in this study are members of the Coleoptera and Lepidoptera (Table 1). A natural history overview was essential to estimating the success of each species and determining collection and rearing strategies. The following is a summary of the biology and effectiveness of each species.

\section{Galerucella calmariensis (Linnaeus) (Black-margined loosestrife beetle) \& Galerucella pusilla (Duftschmidt) (Golden loosestrife beetle)}

The adults of both species are brown, 3-5 mm long and closely resemble each other in appearance and biology, although G. calmariensis adults have longitudinal black markings along the margin of the elytra (Piper et al., 2004a). Females of each species can be distinguished by a notch in the last sternite which is triangular for $G$. calmariensis and rounded for G. pusilla. Both species, native to Asia and Europe were introduced for control of Lythrum salicaria Linneaus (purple loosestrife) in 1992 (Canada and United States) (Piper et al., 2004a).

Galerucella spp. survive well in almost all purple loosestrife habitats (Powell et al., 1994). Adults tend to aggregate on $40 \%$ or less of available plants. This is thought to aid in the location of both mates and good quality hosts (Blossey, 1995; 
Dech and Nosko, 2002). Both species are found in these aggregations on individual host plants even in the presence of unused hosts. Despite overlap in their ecological niche, it is thought that they are unable to competitively displace each other (Blossey, 1995). Cases of one species dominating over another after some years have been noted, but the reasons for this remain unclear (Piper et al., 2004b).

Overwintered adults emerge from the soil in late spring to mate and egg laying begins approximately one week later (Powell et al., 1994). Adults will feed on purple loosestrife leaves, causing damage to the plant (Powell et al., 1994; Piper et al., 2004a). Egg laying continues from May through June and resumes in July and August if emerging adults find suitable conditions to produce another generation (Blossey, 2002). Females of both species can produce between 300 and 400 eggs over a 4-5 week period, although $G$. calmariensis often lays eggs in larger batches than G. pusilla. Eggs of the two species look identical; they are opaque, rounded and covered with a line of frass, and are found on both the upper leaf surface and the stems of purple loosestrife (Blossey, 1995). Galerucella calmariensis and G. pusilla eggs have chemical protection (anthraquinones and dithranol) shown to be effective against ant predators in the genus Myrmica (Hilker, 1994).

Eclosion occurs in 12 days, after which larvae develop through 3 instars over a two week period (Piper et al., 2004a). Larvae of these two species are very similar in appearance and feed first on the leaf and flower buds, moving to feed on all parts of the plant as they mature (Powell et al., 1994). Larvae may also employ chemical defenses to deter predators and parasitoids (Nechols et al., 1996). Once fully developed, larvae enter the leaf litter and soil beneath the plant where they will 
pupate. Pupation lasts from 9-11 days, after which new adults emerge. In general, $G$. pusilla and G. calmariensis produce only one generation per year. In some cases, adults emerging early enough in the season may produce offspring (Powell et al., 1994). In warmer parts of their native range up to four generations have been recorded in a single year (Dech and Nosko, 2002).

\section{Parasitism}

Asecodes mentoWalk. (Hymenoptera: Eulophidea) is known to attack Galerucella spp. larvae in their native range (Malecki et al., 1993; Hamback et al., 2006). Several species of eulophid (Tetrastichus spp. and Pediobius sp.) and tachinid species parasitize members of the Galerucella genus in Europe and North America, and Homalolytus flaminius Dalman (Encyrtidae) has been reared from $G$. calmariensis larvae (Cox, 1994).

\section{Impact (highly successful)}

Galerucella spp. are considered to be highly successful biocontrol agents that have a significant impact on purple loosestrife (Malecki et al., 1993; Blossey et al., 2001). The greatest impact on height and flowering is generally seen $3-5$ years post release (Landis et al., 2003). Studies in Michigan have shown a 75-100\% defoliation of plants in the second year after release and a drop in percent cover from $75-100 \%$ to 0 within 4 years (Landis et al., 2003). Eradication of loosestrife stems was found within 6 years of release at sites in Manitoba (Lindgren, 2003) and New York state (Albright et al., 2004). Oregon and Washington stands were also reduced by up to 90\% (Piper et al., 2004a). Variability in establishment and control has been documented, particularly in British Columbia (Denoth and Myers, 2005). In a 
follow-up to releases made in central New York State, reductions were found at some release sites, but regional density of purple loosestrife was found to be unchanged. Irregular control results are thought to be due to short monitoring time frames (10 years or less) and seasonal changes in beetle density that provide opportunities for purple loosestrife to recover (Grevstad, 2006). Because of their similar effectiveness and the difficulties in distinguishing these two species, I did not differentiate between them for the purposes of this study.

\section{Chrysolina hyperici (Förster) (Klamathweed beetle)}

These beetles, native to northern and central Europe and western Asia, were imported first to California in 1945 and later to British Columbia (1951) for control of Hypericum perforatum Linneaus (St John's wort). Metallic (bronze or green), 4-5 mm adults emerge in June and feed on flower buds and leaves until late July when they aestivate in leaf litter (Powell et al., 1994). Adults remain inactive until cued by rainfall, either in the fall or the following spring, to begin egg laying. Each female can produce several hundred bright orange eggs that eclose in 6-7 days (Piper, 2004).

The larvae are nocturnal feeders that hide during the day under leaves of St John's wort or in the soil surrounding the host plant. They are hump-backed and orange to grey-pink in colour. Larvae feed on the shoot tips and will move to new hosts if a plant becomes completely defoliated (Piper, 2004). Larvae are fully developed by mid-May when they begin to move into the soil beneath the plant on which they have been feeding (Powell et al., 1994). Larvae create cells in the soil for pupation, and will remain there for about 12 days (Piper, 2004). Only one generation of beetles is produced annually (Piper, 2004). 


\section{Parasitism}

Several parasitoid species have been reported to attack $C$. hyperici in its native distribution, these include: Macquartia dispar Fallen, M. tenebricosa (Meigen) and M. tessellum (Meigen) (Hymenoptera: Macquartiini) (Cox, 1994).

\section{Impact (highly successful)}

Chrysolina hyperici is considered to be a highly successful biocontrol agent that can reduce dense patches of St John's wort to a few plants (Harris, 1984; Julien, 1992; Powell et al., 1994). Both larvae and adults inflict damage, increasing the impact on their host plant (Piper, 2004). Reviews of releases made in Ontario have shown St John's wort density reduced by over 95\% (Harris, 1984).

\section{Brachypterolus pulicarius (Linnaeus) (Toadflax flower-feeding beetle)}

Introduced accidentally from its native Europe, the first record of this beetle is in 1919 in the United States and 1920 in Canada (Nowierski, 2004a). Later, intentional releases were made to combat both Linaria vulgaris Linneaus (yellow toadflax) and Linaria genistifolia ssp dalmatica (L.) Miller (Dalmatian toadflax). Beetles can be found surviving in all Linaria spp. habitats, although adults have shown preferences for L. vulgaris (MacKinnon et al., 2005). In spite of this, larval survival appears to be unaffected by the host plant (MacKinnon et al., 2007).

Adults are small (1-2 mm), black, oval-shaped beetles that emerge in May. Mating does not begin until June and only one generation is produced annually (Powell et al., 1994). Adults feed on young toadflax shoots initially, and continue feeding on the host plant through to mid-August. Females lay their eggs singly in the flower buds (Grubb et al., 2002; Nowierski, 2004a). Larvae emerge 3-5 days later 
and feed on the host's reproductive organs and pollen. Later in their development, larvae feed on the seeds (Powell et al., 1994). Larvae will move to new flowers as needed, consuming multiple ovaries during development. Beginning late summer and continuing into the fall, larvae move into the soil to pupate where they remain until the following spring (Grubb et al., 2002).

\section{Impact (moderately successful)}

Both larvae and adults feed on toadflaxes, causing damage to the host plant. Adult feeding, which causes branching and helps suppress early season flowering (Nowierski, 2004a), can be variable among sites and may not have a significant impact on toadflax survival (Egan and Irwin, 2008). Larval feeding also reduces early season flowering and can reduce seed production by $75 \%$ or more on both Linaria species (McClay, 1992; Grubb et al., 2002)

\section{Cassida rubiginosa Muller (Thistle tortoise beetle)}

This univoltine beetle was first recorded in 1901 in Quebec after accidental introduction. Its principle host is Cirsium arvense (L.) Scop. (creeping or Canada thistle) but both adults and larvae feed on other thistle species, of note in this study is Carduus nutans (musk or nodding thistle). Adults are round, green shield beetles that begin to emerge from overwintering in mid-May until June. Egg-laying begins soon after and a single female can produce an average of 815 eggs (laboratory conditions). Eggs are laid on thistle leaves in an oothecum containing approximately 5 eggs each. Females (natural populations) produced 61 ootheca each over a 15-week period and showed no preference for Cirsium or Carduus species (Kok, 2001). Larvae pass through five instars, feeding on thistle foliage, with similar development times on 
Cirsium and Carduus species (27.4 and 28.5 days respectively) (Kok, 2001). Larvae carry a fecal shield (made of exuviae and feces) on spines at the tip of the abdomen, thought to be a deterrent to predators (Bacher and Luder, 2005). Pupation also occurs on thistle leaves, leaving this species exposed through all life stages. New generation adults emerge beginning July through early August (Koji and Nakamura, 2006).

\section{Parasitism}

While the fecal shield carried by $C$. rubiginosa was found to be ineffective against its main predator Polistes dominulus Christ (Hymenoptera: Vespidae), some protection was noted against attack by the parasitoid Foersterella reptans (Hymenoptera: Tetracampidae) in laboratory assays (Bacher and Luder, 2005). Cox (1994) reports that larvae in the Cassidinae belong to the most parasitized subfamily and despite its fecal shield protection, five species of parasitoids have been associated with C. rubiginosa larvae in Virginia (USA): Eucelatoriopsis dimmocki (Aldrich) (Diptera: Tachinidae), Aprostocetus sp. (Hymenoptera: Eulophidea), Itoplectis conquisitor (Say) (Ichneumonidea), Conura torvina (Walsh) (Chalcididae), and Eupelmella vesicularis Ratzeburg (Eupelmidae). Parasitism can be a significant mortality factor during the later part of the season (Kok, 2001). In addition to those found in Virginia, the parasitoids Conura albifrons (Walsh) (Chalcididae), Macroneura vesicularius (Retzius) (Eupelmidae), Tetracampe reptans (Nees) and Foersterella flavipes (Forster) (Tetracampidae), Holcotetrastichus rhosaces (Walker) (Tetrastichinae) have also been reared from C. rubiginosa (Cox, 1994). 


\section{Impact (unsuccessful)}

Cassida rubiginosa is not considered to be a successful control agent.

Damage inflicted by $C$. rubiginosa after thistles have bolted has no noticeable impact on host growth and reproduction. Only when larvae achieve $75 \%$ defoliation at the rosette stage do they have a significant impact on thistle mortality (Kok et al., 2000; Kok, 2001).

\section{Lobesia euphorbiana (Freyer) (Leaf-tying moth)}

Lobesia euphorbiana was first introduced into Canada in 1987 from its native Europe to control Euphorbia esula Linneaus (leafy spurge). Adults are small (10$14 \mathrm{~mm}$ wingspan), brownish, with a white saddle-shaped band across the wings. By mid-June, first generation adults have emerged and begin producing a second generation. Second generation adults generally emerge in late summer and a third generation is possible in southern Ontario. Both mating and egg-laying occur at dawn and dusk. Adults lay single eggs on the lower leaf surface. Each female can produce an average of 55 eggs over their 3-7 day life span (Powell et al., 1994). Upon eclosion, larvae move to the growing tips of the plant and begin rolling leaves together. More leaves and florets will be added to the leaf tie as a larva develops through 4 instars ( 5 instars if food supply is low). A single larva completes development in a leaf tie, forcing out any neighbors. In situations of insufficient food, larvae can be cannibalistic. The last generation of the season overwinters in the larval stage. When fully developed, larvae spin a thick web inside the leaf tie which they use for pupation. The pupal period usually lasts for 26 days (Ministry of Forests and Range, 2008). 


\section{Impact (highly successful)}

Leaf ties created by larvae, and the feeding that occurs at the terminal bud prevents leafy spurge from flowering. This damage can eventually kill the host plant (Ministry of Forests and Range, 2008). Julien (1999) indicates that L. euphorbiana causes "weed death and stem decline over several hectares".

\section{Calophasia lunula (Hufnagel) (Toadflax moth)}

Adult moths are brown with white markings and a 27-30 mm wingspan.

Native to Eurasia, the moth was introduced in 1962 for control of L. vulgaris. Adults begin to emerge in May and mate immediately. Egg-laying begins after 1-2 days and continues through their 3-12 day life span (Powell et al., 1994). Females lay between 30 and 80 eggs, singly, on toadflax leaves. Larvae emerge after 7-11 days and complete their 5 larval instars over a one month period. When young, larvae appear gray, but as they mature bright yellow and black stripes and white markings can be seen along the body (Nowierski, 2004b). Young larvae will feed on toadflax flowers while the later instars feed on the foliage. There are two overlapping generations of C. lunula and larvae can be found from May through early September (Harris, 1984). Once fully developed, larvae construct a pupal chamber from chewed leaves. The chamber is attached to the lower part of the host plant stem or constructed on the soil. Calophasia lunula overwinters in this form (Nowierski, 2004b).

\section{Parasitism}

In its native Europe, $C$. lunula is parasitized by Phryxe vulgaris, while in Canada the tachinid $P$. pecosensis has been associated with this species (Goeden and Louda, 1976). Failure to establish at release sites in Kamloops, British Columbia was 
attributed to pupal parasitism by Dibrachys cavus (Walker) (Hymenoptera:

Pteromalidae) (McClay and Hughes, 1995).

\section{Impact (moderately successful)}

Although severe damage has been seen in some years, feeding damage by $C$. lunula is inconsistent. Additional impact on seed production is seen when young larvae feed on flowers and buds (Nowierski, 2004b). Surveys of Canadian releases show damage to less than $20 \%$ of toadflax stems. On its own, C. lunula is considered to be incapable of controlling toadflax populations (Harris, 1984; Julien, 1992). Larval feeding damage was also found to have no effect on toadflax metabolic processes (photosynthesis, stomatal conductance and transpiration) (Peterson et al., 2005).

\section{Hyles euphorbiae (Linnaeus) (Leafy spurge hawk moth)}

These large natives of southern and central Europe, northern India and central Asia were first introduced in 1966 (Canada and United States) to control Euphorbia cyparissias Linneaus. Adults can have an $8 \mathrm{~cm}$ wingspan with pink, white and black markings. They emerge in spring and are day active, fast fliers and capable of hovering at flowers. During June, females will lay batches of large, round, green eggs on spurge leaves. Between 70 and 150 eggs will be produced per female (Hansen, 2004).

Larvae pass through 5 instars in a 42-72 day period. They change colouration at each stage, from darker early instars to brightly coloured red, black, yellow and white markings at later instars (Powell et al., 1994). This bright colouration may be a warning to predators of the host plant toxins (phorbol esters) that have been found in 
larval skin (Hansen, 2004). Other studies have shown that larvae of H. euphorbiae do not sequester toxins from spurge, but retain them in their gut. When disturbed, larvae regurgitate these toxins in the direction of potential predators (Hundsdoerfer et al., 2005). Larvae may still be susceptible to insect viruses (Hansen, 2004) and predation by ants, mice, wasps, pentatomids and spiders (Harris, 1984).

Pupation occurs in the fall when mature larvae enter the soil and construct a watertight pupal chamber. The pupal period lasts from 15 to 20 days unless overwintering begins (Hansen, 2004). There is usually only one generation per year (Powell et al., 1994)

\section{Impact (unsuccessful)}

Feeding damage by $H$. euphorbiae does not result in plant mortality and this species is largely considered to be an ineffective agent (Julien, 1999; Hansen, 2004). Harris (1984) noted one population in particular that was using less than 5\% of the spurge available at a stable release site, and stated that overall, this species was of "little biological control value".

\section{Rhinocyllus conicus (Frölich) (Thistle seed head weevil)}

Rhinocyllus conicus, a native of Europe, western Asia and North Africa, was originally imported to Canada in 1968 and the United States in 1969. Although it was known to feed on thistle species in the genera Carduus, Cirsium, Silybum and Onoporodum, it was introduced for the control of Carduus nutans Linneaus (musk or nodding thistle) and Carduus acanthoides Linneaus (plumeless thistle) (Harris, 1984; Piper and Coombs, 2004). Adult weevils are dark brown, oval and measure 3-7 mm. They emerge in the spring and feed on thistle foliage through early summer (Powell 
et al., 1994). Starting in early summer, through July, mated females produce between 100 and 150 eggs, laid preferentially on thistle bud bracts. Females cover the egg with a cap of chewed plant material (Piper and Coombs, 2004). The egg-laying period lasts 5-6 weeks and adults will often die 1-2 weeks after the oviposition period ends (Kok, 2001). Over 500 eggs have been counted on a single thistle head (Harris, 1984).

Larvae hatch after 6 to 8 days and make their way into the flower bud from under the layer of chewed material capping the egg (Harris, 1984). They are Cshaped, white larvae with brown head capsules. Development takes 25 to 40 days through 4 instars. Larvae will feed within the upper stems, but mainly feed in the seed heads where they create a chamber coated with feces and plant material. Pupation takes place within the chamber, and lasts from 8 to 14 days (Piper and Coombs, 2004).

New adults spend several weeks inside the pupal chamber. Once they have emerged, they are active for only a short period of time before overwintering, and can live for up to 15 months (Powell et al., 1994; Piper and Coombs, 2004). Emergence can start in July and continue through early August in southern Ontario (Harris, 1984). In general, there is one generation per year, but adults that emerge early enough in the season can produce offspring (Powell et al., 1994).

\section{Parasitism}

Rhinocyllus conicus larvae are known to experience low levels of parasitism in their introduced range by tachinids, and several Hymenoptera parasitoids that are not host specific: Bracon mellitor (Say) (Braconidae), Nealiolus curculionis (Fitch) 
(Braconidae), Zatropis sp. (Pteromalidae), Neocatolaccus sp. (Pteromalidae), and Campoplex polychrosidis Viereck (Ichneumonidae) (Kok, 2001).

\section{Impact (highly successful)}

Larval feeding reduces seed production and so $R$. conicus tends to have the greatest impact on thistles that reproduce solely by seed (C. nutans and $C$.

acanthoides). Larval feeding also causes the plant to redirect nutrients to the site of feeding, further damaging the host (Harris, 1984; Piper and Coombs, 2004). In Virginia, $R$. conicus has been most effective against $C$. nutans, and provides only partial control of C. acanthoides (Kok et al., 2000). Carduus nutans density was reduced $80-95 \%$ in infested pastures shortly after introduction of $R$. conicus in Virginia (Kok, 2001). Within 10 years of release, C. nutans stands in Virginia collapsed and similar patterns have been noted in Oklahoma (Roduner et al., 2003). Julien (1999) also lists $R$. conicus as relatively ineffective against $C$. acanthoides, but effective at controlling C. nutans, indicating that over $70 \%$ of plants are attacked and significantly damaged with density reductions of up to $95 \%$.

\section{Rhinusa (= Gymnaetron) antirrhini (Paykull) (Toadflax seed capsule weevil)}

Introduced accidentally from its native Eurasia, this weevil was first recorded in 1909 in the United States and 1917 in Canada. Later, intentional releases were made to control populations of $L$. vulgaris. Overwintered adults emerge in early spring and feed through May and June (Nowierski, 2004c). Females begin laying eggs on toadflax ovaries at the end of June through mid-August, producing a single generation annually. Hatching occurs 12-17 days later and larvae feed on L. vulgaris seeds through 3 instars. Development is completed in 20 to 30 days, after which 
larvae construct pupation cells within the host seed capsule. Pupation takes 10 to 15 days to complete, and adults will often overwinter in the seed capsule or in debris (Powell et al., 1994; Nowierski, 2004c).

Impact (moderately successful)

This species can significantly reduce toadflax seed production, but in Canada 20-25\% reductions are usually seen (Nowierski, 2004c).

\section{Materials and methods}

\section{Species selection}

A list of candidate biocontrol agents released and established in Ontario and the north eastern United States was developed and agents were ranked according to their effectiveness. This was accomplished by looking at primary biocontrol literature as well as the Julien catalogue of biocontrol agents (Julien, 1992; Julien, 1999), and books documenting biocontrol programs in the United States (Coombs et al., 2004) and Canada (Powell et al., 1994). In biocontrol literature, introduced agents are termed as successful, effective and/or observed reductions in target weed biomass are listed. However, there is a high degree of concordance between sources on the perceived effectiveness of an established agent. Based on the literature, three categories of species were delineated (Table 1): highly successful species that suppress the target weed ( $\geq 90 \%$ reduction in biomass), moderately successful species that control target weed (10\% - 90\% reduction in biomass), and unsuccessful species that are established but have little or no impact on their target weed $(1 \%-10 \%$ reduction in biomass). 


\section{Insect collection}

Field sites were established in and around Ottawa, through Hastings County and in Southern Ontario. For each species included in the study, 3 to 7 collection sites were established. At minimum, $2 \mathrm{~km}$ was maintained between field sites, although most sites were more distant from each other, with up to $75 \mathrm{~km}$ for species collected within the Ottawa region (Breaside-Ottawa) and $500 \mathrm{~km}$ for a single species collected in two different regions of Ontario (Guelph-Ottawa).

The life cycle of each species was used to identify time periods for collection. Between May and October of 2007, field sites were monitored for the presence of each life stage of the species: egg, early larval, late larval, pupal and adult. This was accomplished by sweeping for adults, hand collection of individuals, dissection of collected host plants for eggs larvae and pupae, and sifting of soil samples from field sites for pupae. For univoltine species - G. calmariensis and G. pusilla, C. hyperici, $R$. conicus, B. pulicarius, $R$. antirrhini and C. rubiginosa -- collections were made at each site for each life stage. For the multivoltine species of Lepidoptera $-L$. euphorbiana, C. lunula, H. euphorbiae -- collections were repeated at each site for each generation. Collections were most complete for the late larval stage, and these collections were repeated in the 2008 field season. All data analysis was focused on this life stage. Whenever possible, 2007 sites were reused in 2008 although some were lost to human disturbance. In several cases, population densities (of host plant in insect) were low enough in the 2007 season to warrant replacement of a site in 2008. 
Larvae that were easily identifiable -- G. calmariensis and G. pusilla, C.

hyperici, C. rubiginosa, C. lunula and $H$. euphorbiae -- were hand-collected on site to a maximum of 50 individuals, placed in plastic containers or glass containers with plant material and transported to the laboratory in coolers. Where hand-collection on site was impossible (e.g., for concealed larvae: $R$. conicus, B. pulicarius, $R$. antirrhini and L. euphorbiana) 25 - 50 host plants per site were collected and dissected in the laboratory to locate individuals. For each collection, the total number of larvae was recorded along with the date and site information. Each individual larva was examined for visible signs of parasitism using a dissecting microscope before being placed in a rearing arena.

\section{Insect rearing}

Rearing arenas were constructed using $500 \mathrm{ml}$ plastic water bottles (Figure 1a). The base of the bottle was removed and the lid was punctured using a cork borer of the same circumference as a waterpick tube of approximately $10 \mathrm{~cm}$ (4-inch) in length. Each water pick tube was punctured on one side just below the lid, also using a cork borer. This created a small hole through which each tube could be frequently refilled with water without dismantling the arena during the rearing process. In this way, host plant material was maintained and larvae were allowed to develop with as little disturbance as possible. The water pick tube was then fixed through the lid of the water bottle to create a tight seal and the base of the water bottle was covered by square of mosquito netting (approximately $15 \times 15 \mathrm{~cm}$ ) and secured with an elastic band to provide ventilation. When turned upside down, the water bottle created an enclosed, hydroponic rearing arena standing over the water pick tube (Figure 1a). 
Tubes were held upright in Styrofoam or Aquafoam blocks. Each rearing arena was filled with the appropriate host plant material collected from the field sites, rinsed well and inspected before use. Arenas contained one larva in general, although in some cases in the 2007 field season, multiple larvae of species that feed in close proximity under field conditions were kept in one arena to a maximum of 5 individuals.

The weevil species $R$. conicus and $R$. antirrhini were exceptions to the rearing process. Larvae of these species feed within concealed niches, the seed head and seedpod, respectively, of their host plants. Dissection of host plant material to locate individual larvae rendered the plant material unsuitable for the hydroponic rearing system. Between 5 and 10 larvae were placed, within the seedpod in which they were originally feeding, in a Mason jar (Bernardin Ltd., Toronto, ON) containing a moistened vermiculite substrate. Additional, un-infested, plant material was placed in the jar and the lid was replaced with a square of mosquito netting (approximately $15 \mathrm{x}$ $15 \mathrm{~cm})$ and secured with the Mason jar band.

Arenas were grouped together and kept under a 16:8 light:dark cycle at room temperature $\left(20-25^{\circ} \mathrm{C}\right)$ (Figure $\left.1 \mathrm{~b}\right)$. Visual inspections were conducted every 1-3 days and water pick tubes were refilled daily with water as required. Arenas were opened and fresh plant material was added if existing food became depleted or unsuitable (mouldy or dry). Development information was recorded when observed: date of pupation, date of adult emergence, date of parasitoid emergence. Larvae reared to the pupal stage were treated in several ways depending on the behaviour of the species in question. Moistened vermiculite was added to the bottom of the rearing 
arena for species that prefer to pupate in a soil substrate (G. calmariensis and $G$. pusilla, C. hyperici and B. pulicarius). Hyles euphorbiae pupae were moved individually to a Mason jars containing moistened vermiculite and a small twig standing upright. This allowed emerging adults to move and hang without obstruction as their wings hardened. Pupae of L. euphorbiana, C. rubiginosa and $C$. lunula were most often left to develop undisturbed in the rearing arenas but occasionally individuals were moved to 4-dram vials until emergence. $R$. conicus and $R$. antirrhini individuals were allowed to develop in the Mason jars until emergence.

Individual replicates were allowed to continue to develop until either an adult or parasitoid emerged, the individual died or the replicate could not be located (missing due to death or escape from the arena). Replicates were counted as parasitized once parasitism was observed. In some cases, a parasitoid larvae was observed but not successfully reared to adulthood.

\section{Insect dissection}

Due to the difficulties inherent in rearing concealed larvae after disturbance of the host plant -- R. conicus and R. antirrhini -- a portion of the larvae collected in 2008 were placed immediately into 4-dram vials containing 60\% ethanol solution and later dissected using forceps and a pin vice to determine levels of parasitism.

\section{Voucher specimens}

A portion of individuals successfully reared to adulthood were mounted for identification to establish a voucher collection. Plants of various growth stages were collected at field sites, at the same time as larvae were collected, then pressed and 
mounted to create a voucher collection. Emerged parasitoids were preserved in 3 or 4-dram vials with $70 \%$ ethanol and were mounted and sent to Agriculture and AgriFood Canada for identification.

\section{Analysis}

Data were input into MS Excel 2003 for Windows and all statistical analysis were conducted using SPSS v 13 for Windows. For each field site, proportions were calculated for parasitized larvae, mortality from all other causes, and survival to adulthood. In all cases, missing individuals were excluded from analysis since it could not be determined if they died or escaped from the rearing arenas. ANOVA was used to compare parasitism levels across success categories. Plots of the data revealed opposing trends for moth and beetle species possibly confounded the results. Additional data analysis was performed comparing mean proportions across field sites for the two orders separately, and beetle species were further subdivided into leaf/flower beetles (hereafter beetles) and weevils.

The proportion of beetle individuals parasitized could not be normalized using the arcsin-square root transformation (Kolmogorov-Smirnov: $\mathrm{Z}=1.714, \mathrm{P}=0.006$; nonrandom residual distribution; Levene's Test: $\mathrm{F}=18.797, \mathrm{P}=0.000$ ). A Kruskal-Wallis test was used on untransformed proportions instead. Mann-Whitney pair-wise comparisons were conducted to determine differences between success levels. Lepidopteran species proportions were normalized using the arcsin-square root transformation. ANOVA was used to compare prevalence of parasitism across success levels. Differences between individual success levels were determined using a Tukey's post-hoc analysis. Weevil species data were normalized using the arcsin- 
square root transformation. A t-test was used to compare the proportion parasitized to success for these two species. Analysis was repeated comparing the proportion of individuals that died from causes other than parasitism and the proportion surviving to adulthood to success of the species.

The prevalence of parasitism identified by dissection of weevil species was normalized using the arcsin-square root transformation. A t-test was used to compare the proportion parasitized to success for these two species.

For all species, the year of introduction was compared to the proportion parasitized (arcsin-square root transformed values) using a Spearman's rank correlation.

\section{Results}

\section{Parasitism}

The proportion of larvae parasitized for each species included in the study is shown for both study years (Figure $2 \& 3$ ). When compared across success categories, the proportion of larvae parasitized showed a trend towards decreased parasitism with increasing success in 2007 and 2008, but differences were not significant (2007: $\mathrm{F}=0.21, \mathrm{P}=0.82 ; 2008: \mathrm{F}=0.30, \mathrm{P}=0.75 ;$ Figure 4). By looking at parasitism levels across individual species (Figure $2 \& 3$ ), it appears that that some highly successful species experience high levels of parasitism.

Comparisons across species orders revealed some differences in parasitism trends. Beetle larval parasitism was negatively related to success in both study years (2007: $\chi^{2}=16.82, P=0.00 ; 2008: \chi^{2}=8.35, P=0.02$; Figure 5). Unsuccessful species experienced higher levels of parasitism than either moderately or highly successful 
species. The proportion of moth larvae parasitized increased significantly with success in 2007 ( $F=6.09, P=0.03$; Figure 6). Contrary to beetle species results, parasitism levels were higher for highly successful moth species when compared to moderately successful moths. Highly successful species were more often parasitized than unsuccessful species but the differences were not significant. The same trend, although not significant, was seen in 2008 ( $F=1.07, P=0.38$; Figure 6). Although an inverse trend is visible, the proportion of weevil larvae parasitized did not vary significantly with success (2007: $\mathrm{t}=-1.55, \mathrm{P}=0.18 ; 2008$ : $\mathrm{t}=-1.96, \mathrm{P}=0.09$; Figure 7).

\section{Dissections}

Larval dissections revealed higher levels of parasitism for moderately successful weevils ( $\mathrm{t}=-3.71, \mathrm{P}=0.01$; Figure 8 ).

\section{Introduction year}

Larval parasitism increased significantly with residency time of the species in both study years (2007: Spearman's Rho=-0.44, P=0.01, N=36; 2008: Spearman's Rho=-0.39, $\mathrm{P}=0.02, \mathrm{~N}=34$; Figure 9).

\section{Mortality (other causes)}

The proportion of beetle larvae that died from other causes was not related to success in the either study year $\left(2007: \chi^{2}=3.98, \mathrm{P}=0.14 ; 2008: \chi^{2}=4.02, \mathrm{P}=0.13\right.$; Figure 10). Moth larval mortality was not influenced by success in 2007 ( $F=0.09$, $\mathrm{P}=0.92$; Figure 11), but mortality of unsuccessful species was higher than moderately and highly successful species in $2008(\mathrm{~F}=10.08, \mathrm{P}=0.01$; Figure 11). The proportion of weevil larvae that died from causes other than parasitism was not related to success 
in $2007(\mathrm{t}=-1.05, \mathrm{P}=0.34$; Figure 12$)$. However, in 2008, highly successful species suffered significantly lower mortality than moderately successful species $(\mathrm{t}=3.14$, $\mathrm{P}=0.02$; Figure 12).

\section{Survivorship}

When compared across success levels, the proportion of larvae surviving to adulthood showed a trend towards increased survival with increasing success in 2008, but differences were not significant in either study year $(2007: \mathrm{F}=0.79, \mathrm{P}=0.50 ; 2008$ : $\mathrm{F}=0.33, \mathrm{P}=0.73$; Figure 13). By looking at survival across individual species differing trends among species are visible.

Larval survival for moderately and unsuccessful beetles was lower than that of highly successful species in 2008 , but not in 2007 (2007: $\chi^{2}=4.62, \mathrm{P}=0.1 ; 2008$ :

$\chi^{2}=6.86, \mathrm{P}=0.03$; Figure 14 ). Although, moth survival to adulthood was not related to success in 2007 ( $F=0.86, P=0.46$; Figure 15), survival was better for highly successful species when compared to unsuccessful species in 2008 ( $F=6.46, P=0.02$; Figure 15). Weevil survival to adulthood was not related to success in either study year (2007: $t=2.26, P=0.07 ; 2008: t=0.54, P=0.61 ;$ Figure 16).

\section{Discussion}

The enemy release hypothesis predicts that introduced species will be free from their specialist natural enemies in new geographic regions (Keane and Crawley, 2002). Experimental support for this hypothesis has been mixed for both introduced plants and insects. Here, we use weed biocontrol agents as an example of introduced species, substituting the success of an agent for invasiveness to investigate the 
relationship between parasitism, survival and success as an introduced species. Our results are no less mixed than other empirical studies, showing partial adherence to the predictions of the ERH for beetle species and paradoxical results for moth species.

\section{Parasitism}

While there is a trend towards escape from parasitoid natural enemies with increasing success (Figure 4), differing trends between species orders may be confounding this relationship. Lepidopteran larval parasitism increased with success as an introduced species in direct contrast to predictions of the enemy release hypothesis (Figure 6). The most successful species, L. euphorbiana, was more likely to be parasitized than the moderately successful $C$. lunula and experienced higher (although not significantly) parasitism than the least successful moth, $H$. euphorbiae. On the other hand, parasitism of beetle species was negatively associated with success (Figure 5). The most successful beetles, G. calmariensis, G. pusilla and $C$. hyperici experienced lower parasitism than their least successful counterpart, $C$. rubiginosa.

Past studies with plants have shown equivocal support for the enemy release hypothesis. Reduced numbers of pathogens and herbivores have been documented for exotic plants in their introduced versus their native range (Wolfe, 2002; Mitchell and Power, 2003; Liu and Stiling, 2006). However, comparisons of herbivory on congeneric pairs of native and introduced plants resulted in higher herbivory on introduced plants in one study year and lower herbivory in a subsequent year (Agrawal and Kotanen, 2003; Agrawal et al., 2005). Comparison of introduced Eugenia spp. (both invasive and non-invasive) and their native congeners, resulted in 
less herbivory on introduced versus native species but no difference in herbivory between invasive and non-invasive introduced plants (Liu et al., 2007). In the present study, we find partial support for the ERH in levels of parasitism of beetle species and paradoxical results for moth species. One possible explanation is that release from natural enemies alone does not guarantee invasion success. Introduced species must be able in some way, to take advantage of reduced natural enemy pressure (Keane and Crawley, 2002). The most successful moth species in this study succeeded in spite of heavy parasitism, while the least successful moth species remained relatively innocuous in spite of lower levels of natural enemy attack. Beetles may be in some way better suited to take advantage of a reduced enemy environment to become highly successful. It should be noted that natural enemies may indirectly limit species populations through reduction to the point where other processes cause extinction (inbreeding depression, Allee effects, etc.) (Ehler, 1998). Another assumption underlying the ERH is that natural enemies exert enough pressure to limit prey populations in their native ranges (Maron and Vila, 2001). Following this assumption, the loss of such an enemy, against which the prey species has little resistance, will have far more consequence than the loss of enemies against which they are well defended (Colautti et al., 2004). Enemy release may play a vital role in introduced species success if critical species of natural enemy are left behind. Meta analysis of introduced plants have supported this contention, showing reduced complements of specialist herbivore diversity and in particular, reduced diversity of herbivores that feed on reproductive parts in their introduced ranges (Liu and Stiling, 2006). For example, biocontrol of Cirsium canescens through the introduction of 
seed feeders has been successful because these herbivores are known to control the host plant in their native range (Maron and Vila, 2001). In terms of this study, parasitoid natural enemies may not limit species populations in their native range, resulting in their loss when introduced to new geographic ranges being of little consequence.

Predators and pathogens, not accounted for in the present study, are often suggested to have a greater impact than parasitoids for introduced insect populations. This may in part explain the current results, if successful moth species suffer lower levels of predation and disease, comparing levels of parasitism alone obscures the benefits enjoyed by those species. The effect of predation has largely been ignored in biocontrol despite growing evidence of the impact on food webs (Pearson and Callaway, 2003). Failure to establish and reduced efficacy of agents has been attributed to predation in several biocontrol programs (Goeden and Louda, 1976; Ehler, 1998). Predation has also been cited as more influential than parasitism or disease for invasive species establishment and control (Crawley, 1986; Ehler, 1998). A case in point involves predation by deer mice (Peromyscus maniculatus) of two gall fly species, Urophora affinis and U. quadrifasciata, introduced for the control of Centaurea maculosa. Deer mice readily made gall flies a principle part of their diet, restricting gall fly impact (Pearson et al., 2000; Pearson and Callaway, 2003; Pearson and Callaway, 2005).

Another important assumption of the ERH is that host switching by native specialists will be rare (Keane and Crawley, 2002). Clearly, introduced species in this study experience parasitism, but the source of colonizers is unknown pending 
identification of reared specimens. Possible sources of parasitoids are coevolved species accidentally introduced from the native range, or resident parasitoids that may have made the switch to a novel host, both of which have implications for the ERH. Biocontrol agents are introduced free of associated parasitoids from their native range (Keane and Crawley, 2002). However, some herbivores now considered to be biocontrol agents were originally introduced accidentally, several of which were included in this study, allowing the possibility that coevolved natural enemies were unintentionally introduced along with them. These unintentional introductions of herbivores and their associated parasitoids may occur even after initiation of formal release programs. Herbivores introduced with coevolved natural enemies that continue on to high degrees of success would be direct evidence against the ERH.

It is equally possible that parasitoids reared from herbivores in this study are resident species. Accumulation of native natural enemies is well documented, with variable impact of resident species against non-native plants (Maron and Vila, 2001), and non-native herbivores (Goeden and Louda, 1976; Godfray et al., 1995; Hill and Hulley, 1995; Dhileepan et al., 2005; Vercher et al., 2005; Klug et al., 2008). For example, $40 \%$ of introduced biocontrol agents in South Africa experienced low levels of parasitism by resident species (Hill and Hulley, 1995). In accordance with ERH predictions, these cases often involve higher proportions of generalist natural enemies and low levels of overall parasitism. Cornell and Hawkins (1993), in a comparison of insects in their native and introduced ranges, found that the fauna supported by exotics was often more diverse than that in their native range but consisted of more generalist than specialist species. They surmised that an adjustment in this ratio may 
take time to become evident. In our study, multiple species of parasitoid were often reared from a host species. This may be attributable to incidental attacks by resident species coming into contact with a novel host (Cornell and Hawkins, 1993).

However, the high level of parasitism recorded for some species in this study suggests the involvement of specialists, whether coevolved or resident, and runs contrary to ERH assumptions.

Taxonomic isolation is thought to play a role in invasion success for plants, possibly by mediating the accumulation of specialist natural enemies (Lockwood et al., 2001; Agrawal and Kotanen, 2003). Non-target effects in weed biocontrol most often result in shifts to close relatives of the target weed (Louda et al., 2003). Taxonomic isolation may be especially important in allowing herbivores to escape attack by parasitoids, since parasitism is thought to require a tight coevolutionary relationship (Cornell and Hawkins, 1993). Thus, herbivores closely related to resident species may be colonized more readily by parasitoids associated with their native relatives (Godfray et al., 1995). Cornell and Hawkins (1993) note that species with a rich parasitoid complex in their native range tend to have rich parasitoid complexes in their introduced ranges. They propose a "vulnerability to parasitism" resulting from common host biology that may elicit parasitoid response, particularly from resident parasitoids belonging to the same genus as coevolved parasitoids (Cornell and Hawkins, 1993). Our results for parasitism of C. rubiginosa, a member of the most heavily parasitized subfamily of chrysomelid beetles according to Cox (1994), certainly seem to suggest some truth to this hypothesis. 
Establishment of introduced species may be facilitated by enemy release, but subsequent accumulation of natural enemy complexes at variable rates may limit species populations. Crashes of previously invasive populations of introduced species are often attributed to disease, but may in some cases be attributable to natural enemies (Simberloff and Gibbons, 2004). In our study, the most heavily parasitized species may simply belong to more ubiquitous taxa, or have a larger pool of potential colonizers, resulting in faster accumulation of natural enemy species. While there is little experimental support for the role of taxonomic isolation, follow-up studies are needed to determine the relative rates at which species accumulate natural enemies and the impact this has on their success as invaders.

\section{Dissections}

Parasitism did not correlate with invasion success for reared weevils, although a negative trend between success and parasitism is certainly visible (Figure 7). Dissections of weevil larvae clarified this relationship and resulted in significantly higher parasitism for R. antirrhini, a moderately successful species (Figure 8). However, in the absence of an unsuccessful species for comparison, this provides only limited support for the ERH. Our results do, however, suggest that parasitism levels may be underestimated for all study species. A portion of parasitoids failed to fully develop possibly due to disturbance during the collection and rearing process, background mortality of the parasitoid species or incidental attack by parasitoids incapable of complete development on the novel host. From the standpoint of the enemy release hypothesis, the impact on the prey species is the same irrespective of 
survival of the parasitoid. More accurate estimation of natural enemy occurrence is required to fully understand their interactions with introduced species.

\section{Introduction year}

Introduction year was negatively correlated with prevalence of parasitism in both study years (Figure 9). Evolution of natural enemy associations are thought to be correlated with residency time, particularly for specialist natural enemies that may need to develop specializations to colonize a novel host (Cornell and Hawkins, 1993; McEvoy, 2002). However, evidence of a correlation between residency time and natural enemy load has been mixed. Carpenter and Cappuccino (2005) found no correlation between introduction year and herbivory for invasive plants. Similarly, increased parasitoid assemblages have not been found over time for introduced insects, although level of attack by native parasitoids has been shown to increase (Cornell and Hawkins, 1993; Dhileepan et al., 2005). In some cases, introductions may be too recent for comparisons to be meaningful, or too distant for differences to be evident if natural enemy accumulation occurs rapidly. Further study is necessary to determine if the correlation found in this study is altered by removing generalist parasitoids from the comparison.

Geographic spread after colonization is likely correlated to time since introduction. Broad distribution of introduced plants has been linked to increased colonization by herbivores and fungal pathogens (Strong, 1974; Clay, 1995; Torchin and Mitchell, 2004; Agrawal et al., 2005). For established non-native insects, range expansion should put them in contact with more parasitoid species increasing the rate of colonization (Cornell and Hawkins, 1993). Unfortunately, information on 
geographical spread of introduced species is lacking, even for biocontrol agents, making comparisons difficult. Given that range expansion of biocontrol agents is hastened by human intervention, this effect may be amplified for some biocontrol species. Differences in the relative distribution of species in this study could, in part, explain levels of parasitism contrary to predictions for the highly successful moth species.

\section{Mortality (other causes)}

Mortality from other causes including parasitoids that failed to develop, pathogens and parasites, or general intolerance of disturbance, showed variable correlations with success as an invader. Beetle species mortality did not correlate with success in either study season (Figure 10). The lack of correlation was seen for moth and weevil species in 2007, however in 2008 unsuccessful species of moth and weevil suffered higher mortality (Figure $11 \& 12$ ).

While a portion of this additional mortality may be due to parasitism, pathogens may also play a role in introduced species success. At least some of the individuals in this study were infected with the fungal pathogen, Beauvaria bassiana, but accurate estimates of the prevalence of infection could not be made for all species. The impact of disease has traditionally been considered negligible for introduced weed biocontrol agents (Goeden and Louda, 1976; Ehler, 1998) although pathogens are often cited as the reason for introduced species population fluctuations (Simberloff and Gibbons, 2004), without empirical evidence to support either conclusion. While reduced pathogen load has been associated with invasive plants in their introduced ranges (Mitchell and Power, 2003), the effect of entomopathogens is 
often underrepresented in ecological studies (Crawley, 1986). Despite the ability of pathogens to influence insect populations, the lack of study of host-pathogen interactions may result directly from past taxonomic difficulties and the varied effects of pathogens on insects (Bonsall, 2004).

\section{Survival to adulthood}

The enemy release hypothesis leads directly to the prediction of higher survivorship for successful invaders, implying that they must be generally more robust and capable of surviving diverse conditions. In this study, there was a trend, although not significant, of higher survival with increasing success as an invader in 2008 (Figure 13). Differing trends between species may be confounding this relationship. Survival to adulthood in this study was greater for highly successful beetles in 2008 (Figure 14). Moth species survival did not correlate with success as an invader in 2007 , but was higher for highly successful versus unsuccessful species in 2008 (Figure 15). For weevils, a trend of increased survival for highly successful species can be seen, but is not significant in either study year (Figure 16). As predicted, there is an overall trend of greater survival to adulthood for all highly successful species in this study. Of particular interest, is survival for the highly successful moth, L. euphorbiana, despite higher levels of parasitism than their less successful counterparts. Unless introduced species can capitalize on the benefits of reduced natural enemy attack, they may not become successful invaders (Keane and Crawley, 2002). Insects can be colonized by multiple enemies such as pathogens, parasites, mircrosporidians, gregarines and nematodes, all of which may have sublethal effects but may contribute to a lack of robustness. Our results indicate that the 
effects of other mortality factors outweigh the impact of parasitoids for introduced moths, and suggest that unsuccessful species are not as robust as successful species and as such may not benefit from reduced natural enemy pressure.

\section{Conclusion}

To our knowledge, this is the first attempt at contrasting natural enemy pressure on invasive and non-invasive introduced insects, with unexpected results. Parasitoid natural enemies appeared to play a role in the success or failure of leaf/flower beetle species, and potentially for weevils, while moth species showed a pattern contrary to that predicted based on the enemy release hypothesis. This demonstrates the need to more accurately identify natural enemies that limit host populations in their native range. Understanding the role of natural enemies may help to determine if enemy release will facilitate exotic species establishment and spread. Improvements can also be made to biocontrol programs by understanding how species succeed in spite of natural enemy pressures.

Relatedness of introduced species to native congeners and vulnerability to colonisation by close relatives of coevolved natural enemies also deserves further study. We demonstrate a link between residency time and parasitism, which may be directly influenced by these factors. Considerations such as this could have implications for biocontrol programs as well as invasive species management.

Inclusion of a broad range of natural enemies, including those with sub-lethal effects, and their cumulative impact on introduced species may provide more useful assessments of the role of enemy release in species invasions. We have provided 
evidence that herbivore survival is not always directly linked to obvious forms of natural enemy interactions.

It should be noted that, while biocontrol releases provide substantial opportunities for ecological study, results should be interpreted with caution. Few attempts have been made at rigorous comparisons of the impact of biocontrol agents (Carson et al., 2008), making comparisons with these species as difficult as those with unintentionally introduced species. Despite their difficulties, studies such as this warrant further efforts to identify new ways to mediate the impact of invasive species. 


\section{References}

Agrawal, A. A., and P. M. Kotanen. 2003. Herbivores and the success of exotic plants: a phylogenetically controlled experiment. Ecology Letters 6:712-715.

Agrawal, A. A., P. M. Kotanen, C. E. Mitchell, A. G. Power, W. Godsoe, and J. Klironomos. 2005. Enemy release? An experiment with congeneric plant pairs and diverse above- and belowground enemies. Ecology 86:2979-2989.

Albright, M. F., W. N. Harman, S. S. Fickbohm, H. Meehan, S. Groff, and T. Austin. 2004. Recovery of native Flora and behavioral responses by Galerucella spp. following biocontrol of purple lossestrife. American Midland Naturalist 152:248-254.

Bacher, S., and S. Luder. 2005. Picky predators and the function of the faecal shield of a cassidine larva. Functional Ecology 19:263-272.

Blossey, B. 1995. Coexistence of two leaf-beetles in the same fundamental niche. Distribution, adult phenology and oviposition. Oikos 74:225-234.

Blossey, B. 2002. Purple loosestrife. Pages 149-157 in R. Van Driesche, S. Lyon, B. Blossey, M. Hoddle, and R. Reardon, editors. Biological control of invasive plants in the eastern United States. USDA Forest Service.

Blossey, B., L. C. Skinner, and J. Taylor. 2001. Impact and management of purple loosestrife (Lythrum salicaria) in North America. Biodiversity and Conservation 10:1787-1807.

Bonsall, M. B. 2004. The impact of diseases and pathogens on insect population dynamics. Physiological Entomology 29:223-236.

Callaway, R. M., and E. T. Aschehoug. 2006. Invasive plants versus their new and old neighbours: a mechanism for exotic invasion. Science 291:521-523.

Cappuccino, N., and D. Carpenter. 2005. Invasive exotic plants suffer less herbivory than non-invasive exotic plants. Biology Letters 1:435-438.

Carpenter, D., and N. Cappuccino. 2005. Herbivory, time since introduction and the invasiveness of exotic plants. Journal of Ecology 93:315-321.

Carson, W. P., S. M. Hovick, A. J. Baumert, D. E. Bunker, and T. H. Pendergast. 2008. Evaluating the post-release efficacy of invasive plant biocontrol by insects: a comprehensive approach. Arthropod-Plant Interactions 2:77-86.

Clay, K. 1995. Correlates of pathogen species richness in the grass family. Canadian Journal of Botany 73:S42-S49.

Colautti, R. I., A. Ricciardi, I. A. Grigorovich, and H. J. MacIsaac. 2004. Is invasion success explained by the enemy release hypothesis? Ecology Letters 7:721733.

Coombs, E. M., J. K. Clark, G. L. Piper, and A. F. Cofrancesco, Jr, editors. 2004. Biological Control of invasive plants in the United States, First edition. Oregon State University Press, Corvallis, Oregon.

Cornell, H. V., and B. A. Hawkins. 1993. Accumulation of Native Parasitoid Species on Introduced Herbivores - a Comparison of Hosts as Natives and Hosts as Invaders. American Naturalist 141:847-865.

Cox, M. L. 1994. The Hymenoptera and Diptera parasitoids of Chrysomelidae. Pages 419-468 in P. H. Jolivet, M. L. Cox, and E. Petitpierre, editors. Novel aspects 
of the biology of Chrysomelidae. Kluwer Academic Publishers, Dordrecht, Netherlands.

Crawley, M. J. 1986. The Population Biology of Invaders. Philosophical Transactions of the Royal Society of London Series B-Biological Sciences 314:711-731.

Dech, J. P., and P. Nosko. 2002. Population establishment, dispersal, and impact of Galerucella pusilla and G-calmariensis, introduced to control purple loosestrife in Central Ontario. Biological Control 23:228-236.

Denoth, M., and J. H. Myers. 2005. Variable success of biological control of Lythrum salicaria in British Columbia. Biological Control 32:269-279.

Dhileepan, K., C. J. Lockett, and R. E. McFadyen. 2005. Larval parasitism by native insects on the introduced stem-galling moth Epiblema strenuana Walker (Lepidoptera : Tortricidae) and its implications for biological control of Parthenium hysterophorus (Asteraceae). Australian Journal of Entomology 44:83-88.

Egan, J. F., and R. E. Irwin. 2008. Evaluation of the field impact of an adventitious herbivore on an invasive plant, yellow toadflax, in Colorado, USA. Plant Ecology 199:99-114.

Ehler, L. E. 1998. Invasion biology and biological control. Biological Control 13:127-133.

Godfray, H. C. J., D. J. L. Agassiz, D. R. Nash, and J. H. Lawton. 1995. The Recruitment of Parasitoid Species to 2 Invading Herbivores. Journal of Animal Ecology 64:393-402.

Goeden, R. D., and S. M. Louda. 1976. Biotic Interference with Insects Imported for Weed-Control. Annual Review of Entomology 21:325-342.

Grevstad, F. S. 2006. Ten-year impacts of the biological control agents Galerucella pusilla and G-calmariensis (Coleoptera : Chrysomelidae) on purple loosestrife (Lythrum salicaria) Central New York State. Biological Control 39:1-8.

Grubb, R. T., R. M. Nowierski, and R. L. Sheley. 2002. Effects of Brachypterolus pulicarius (L.) (Coleoptera: Nitidulidae) on growth and seed production of Dalmatian toadflax, Linaria genistifolia ssp. dalmatica (L.) Maire and Petitmengin (Scrophulariaceae). Biological Control 23:107-114.

Hamback, P. A., J. A. Stenberg, and L. Ericson. 2006. Asymmetric indirect interactions mediated by a shared parasitoid: connecting species traits and local distribution patterns for two chrysomelid beetles. Oecologia (Berlin) 148:475-481.

Hansen, R. W. 2004. Hyles euphorbiae. Pages 254-256 in E. M. Coombs, J. K. Clark, G. L. Piper, and A. F. Cofrancesco, Jr, editors. Biological Control of invasive plants in the United States. Oregon State University Press, Corvallis, Oregon.

Harris, P. 1984. Biological control of weeds in Canada 1969-80. Pages 95-211 in J. S. Kelleher and M. A. Hulme, editors. Biological control programmes against insects and weeds in Canada 1969-1980. Commonwealth Agricultural Bureaux, Slough, England.

Hilker, M. 1994. Egg deposition and protection of eggs in Chrysomelidae. Pages 263276 in P. H. Jolivet, M. L. Cox, and E. Petitpierre, editors. Novel aspects of 
the biology of Chrysomelidae. Kluwer Academic Publishers, Dordrecht, The Netherlands.

Hill, M. P., and P. E. Hulley. 1995. Host-Range Extension by Native Parasitoids to Weed Biocontrol Agents Introduced to South-Africa. Biological Control 5:297-302.

Hundsdoerfer, A. K., J. N. Tshibangu, B. Wetterauer, and M. Wink. 2005. Sequestration of phorbol esters by aposematic larvae of Hyles euphorbiae (Lepidoptera : Sphingidae)? Chemoecology 15:261-267.

Julien, M. H. 1992. Biological control of weeds: a world catalogue of agents and their target weeds, Third Edition edition. CAB International, Wallingford, UK.

Julien, M. H. 1999. Biological control of weeds: a world catalogue of agents and their target weeds, Fourth Edition. Oxford University Press, Wallingford, UK.

Keane, R. M., and M. J. Crawley. 2002. Exotic plant invasions and the enemy release hypothesis. Trends in Ecology \& Evolution 17:164-170.

Klug, T., R. Meyhofer, M. Kreye, and M. Hommes. 2008. Native parasitoids and their potential to control the invasive leafminer, Cameraria ohridella DESCH \& DIM. (Lep.: Gracillariidae). Bulletin of Entomological Research 98:379387.

Koji, S., and K. Nakamura. 2006. Seasonal fluctuation, age structure, and annual changes in a population of Cassida rubiginosa (Coleoptera : Chrysomelidae) in a natural habitat. Annals of the Entomological Society of America 99:292299.

Kok, L. T. 2001. Classical biological control of nodding and plumeless thistles. Biological Control 21:206-213.

Kok, L. T., T. J. McAvoy, and W. T. Mays. 2000. Successful establishment of exotic agents for classical biological control of invasive weeds in Virginia. Pages 5965 in N. R. Spencer, editor. Proceedings of the X International Symposiumon Biological Control of Weeds, Montana.

Landis, D. A., D. C. Sebolt, M. J. Haas, and M. Klepinger. 2003. Establishment and impact of Galerucella calmariensis L. (Coleoptera : Chrysomelidae) on Lythrum salicaria L. and associated plant communities in Michigan. Biological Control 28:78-91.

Lindgren, C. J. 2003. Using 1-min scans and stem height data in a post-release monitoring strategy for Galerucella calmariensis (L.) (Coleoptera : Chrysomelidae) on purple loosestrife, Lythrum salicaria L. (Lythraceae), in Manitoba. Biological Control 27:201-209.

Liu, H., and P. Stiling. 2006. Testing the enemy release hypothesis: a review and meta-analysis. Biological Invasions 8:1535-1545.

Liu, H., P. Stiling, and R. W. Pemberton. 2007. Does enemy release matter for invasive plants? evidence from a comparison of insect herbivore damage among invasive, non-invasive and native congeners. Biological Invasions 9:773-781.

Lockwood, J. L., D. Simberloff, M. L. McKinney, and B. Von Holle. 2001. How many, and which, plants will invade natural areas? Biological Invasions 3:1-8.

Louda, S. M., R. W. Pemberton, M. T. Johnson, and P. A. Follett. 2003. Nontarget effects - the achilles' heel of biological control? Retrospective analysis to 
reduce risk associated with biocontrol introductions. Annual Review of Entomology 48:365-396.

MacKinnon, D. K., R. A. Hufbauer, and A. P. Norton. 2005. Host-plant preference of Brachypterolus pulicarius, an inadvertently introduced biological control insect of toadflaxes. Entomologia Experimentalis et Applicata 116:183-189.

MacKinnon, D. K., R. A. Hufbauer, and A. P. Norton. 2007. Evaluating host use of an accidentally introduced herbivore on two invasive toadflaxes. Biological Control 41:184-189.

Malecki, R. A., B. Blossey, S. D. Hight, D. Schroeder, L. T. Kok, and J. R. Coulson. 1993. Biological-Control of Purple Loosestrife. Bioscience 43:680-686.

Maron, J. L., and M. Vila. 2001. When do herbivores affect plant invasion? Evidence for the natural enemies and biotic resistance hypotheses. Oikos 95:361-373.

McClay, A. S. 1992. Effects of Brachypterolus-Pulicarius (L) (Coleoptera, Nitidulidae) on Flowering and Seed Production of Common Toadflax. Canadian Entomologist 124:631-636.

McClay, A. S., and R. B. Hughes. 1995. Effects of Temperature on Developmental Rate, Distribution, and Establishment of Calophasia-Lunula (Lepidoptera, Noctuidae), a Biocontrol Agent for Toadflax (Linaria Spp). Biological Control 5:368-377.

McEvoy, P. B. 2002. Insect-plant interactions on a planet of weeds. Entomologia Experimentalis et Applicata 104:165-179.

Ministry of Forests and Range. 2008. Biological Control Agent: Lobesia euphorbiana (Freyer). in. BC Government

Mitchell, C. E., and A. G. Power. 2003. Release of invasive plants from fungal and viral pathogens. Nature 421:625-627.

Nechols, J. R., J. J. Obrycki, C. A. Tauber, and M. J. Tauber. 1996. Potential impact of native natural enemies on Galerucella spp (Coleoptera: Chrysomelidae) imported for biological control of purple loosestrife: A field evaluation. Biological Control 7:60-66.

Nowierski, R. M. 2004a. Brachypterolus pulicarius. Pages 383-384 in E. M. Coombs, J. K. Clark, G. L. Piper, and A. F. Cofrancesco, Jr, editors. Biological Control of invasive plants in the United States. Oregon State University Press, Corvallis, Oregon.

Nowierski, R. M. 2004b. Calophasia lunula. Pages 384-386 in E. M. Coombs, J. K. Clark, G. L. Piper, and A. F. Cofrancesco, Jr, editors. Biological Control of invasive plants in the United States. Oregon State University Press, Corvallis, Oregon.

Nowierski, R. M. 2004c. Gymnetron antirrhini. Pages 389-391 in E. M. Coombs, J. K. Clark, G. L. Piper, and A. F. Cofrancesco, Jr, editors. Biological Control of invasive plants in the United States. Oregon State University Press, Corvallis, Oregon.

Pearson, D. E., and R. M. Callaway. 2003. Indirect effects of host-specific biological control agents. Trends in Ecology \& Evolution 18:456-461.

Pearson, D. E., and R. M. Callaway. 2005. Indirect nontarget effects of host-specific biological control agents: Implications for biological control. Biological Control 35:288-298. 
Pearson, D. E., K. S. McKelvey, and L. F. Ruggiero. 2000. Non-target effects of an introduced biological control agent on deer mouse ecology. Oecologia 122:121-128.

Peterson, R. K. D., S. E. Sing, and D. K. Weaver. 2005. Differential physiological responses of Dalmatian toadflax, Linaria dalmatica L. Miller, to injury from two insect biological control agents: Implications for decision-making in biological control. Environmental Entomology 34:899-905.

Piper, G. L. 2004. Chrysolina hyperici. Pages 327-329 in E. M. Coombs, J. K. Clark, G. L. Piper, and A. F. Cofrancesco, Jr, editors. Biological Control of invasive plants in the United States. Oregon State University Press, Corvallis, Oregon.

Piper, G. L., and E. M. Coombs. 2004. Rhinocyllus conicus. Pages 365-368 in E. M. Coombs, J. K. Clark, G. L. Piper, and A. F. Cofrancesco, Jr, editors. Biological Control of invasive plants in the United States. Oregon State University Press, Corvallis, Oregon.

Piper, G. L., E. M. Coombs, B. Blossey, P. B. McEvoy, and S. S. Schooler. 2004a. Galerucella calmariensis. Pages 282-284 in E. M. Coombs, J. K. Clark, G. L. Piper, and A. F. Cofrancesco, Jr, editors. Biological Control of invasive plants in the United States. Oregon State University Press, Corvallis, Oregon.

Piper, G. L., E. M. Coombs, B. Blossey, P. B. McEvoy, and S. S. Schooler. 2004b. Galerucella pusilla. Pages 285-287 in E. M. Coombs, J. K. Clark, G. L. Piper, and A. F. Cofrancesco, Jr, editors. Biological Control of invasive plants in the United States. Oregon State University Press, Corvallis, Oregon.

Powell, G. W., A. W. Sturko, Brian M., and P. Harris. 1994. Field guide to the biological control of weeds in British Columbia. Research Branch, Ministry of Forests, Victoria, BC.

Roduner, M. A., G. Cuperus, P. Mulder, J. Stritzke, and M. Payton. 2003. Successful biological control of the musk thistle in Oklahoma using the musk thistle head weevil and the rosette weevil. American Entomologist 49:112-120.

Shea, K., and P. Chesson. 2002. Community ecology theory as a framework for biological invasions. Trends in Ecology \& Evolution 17:170-176.

Simberloff, D., and L. Gibbons. 2004. Now you see them, now you don't - population crashes of established introduced species. Biological Invasions 6:161-172.

Strong, D. R. 1974. Rapid Asymptotic Species Accumulation in Phytophagous Insect Communities - Pests of Cacao. Science 185:1064-1066.

Torchin, M. E., and C. E. Mitchell. 2004. Parasites, pathogens, and invasions by plants and animals. Frontiers in Ecology and the Environment 2:183-190.

Van Driesche, R. G., and T. S. Bellows. 1996. Biological Control. Chapman \& Hall, New York, USA.

Vercher, R., J. Costa-Comelles, C. Marzal, and F. Garcia-Mari. 2005. Recruitment of Native Parasitoid Species by the Invading Leafminer Phyllocnistis citrella (Lepidoptera : Gracillariidae) on Citrus in Spain. Environmental Entomology 34:1129-1138.

Wolfe, L. M. 2002. Why alien invaders succeed: Support for the escape-from-enemy hypothesis. American Naturalist 160:705-711. 


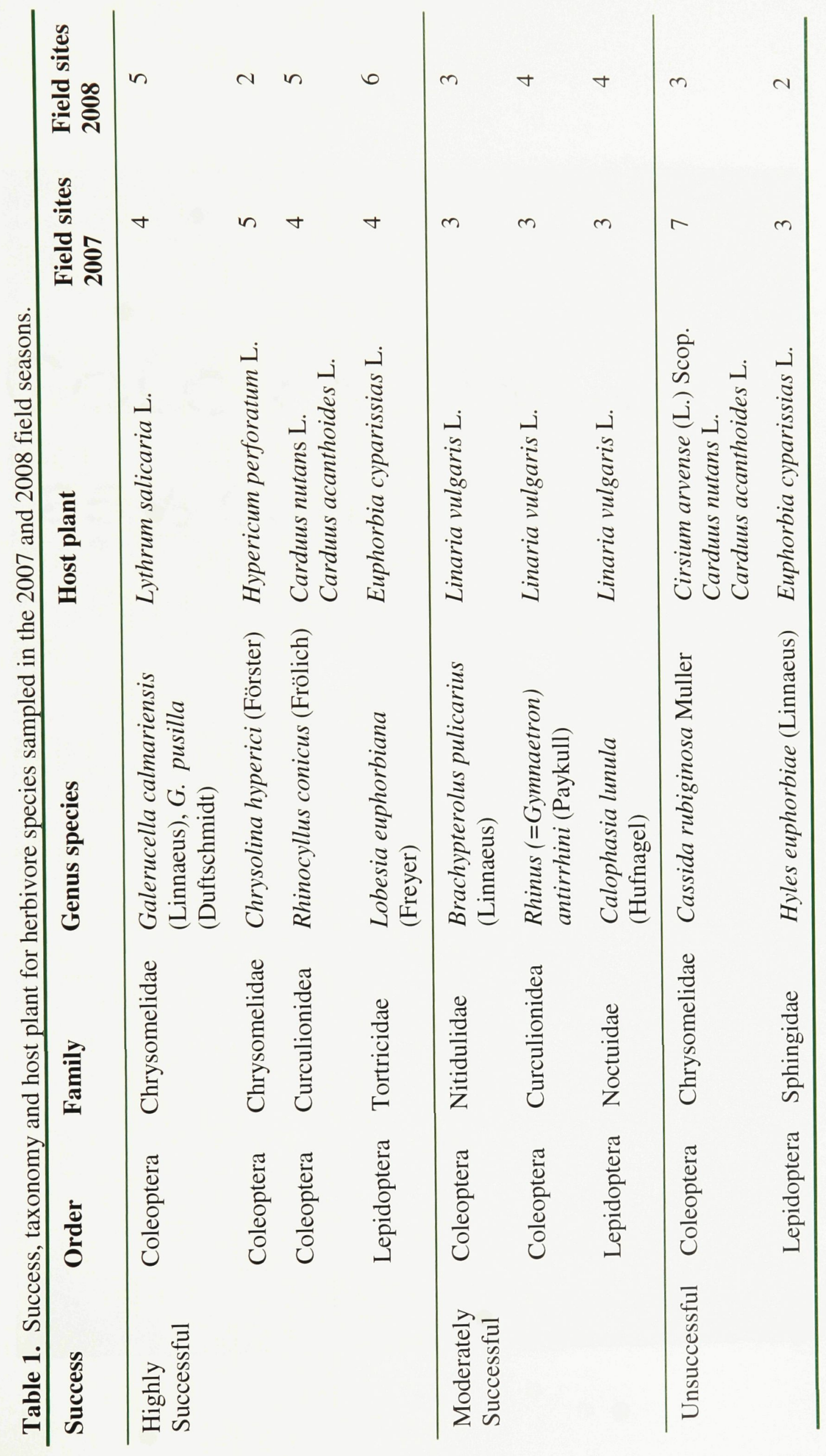




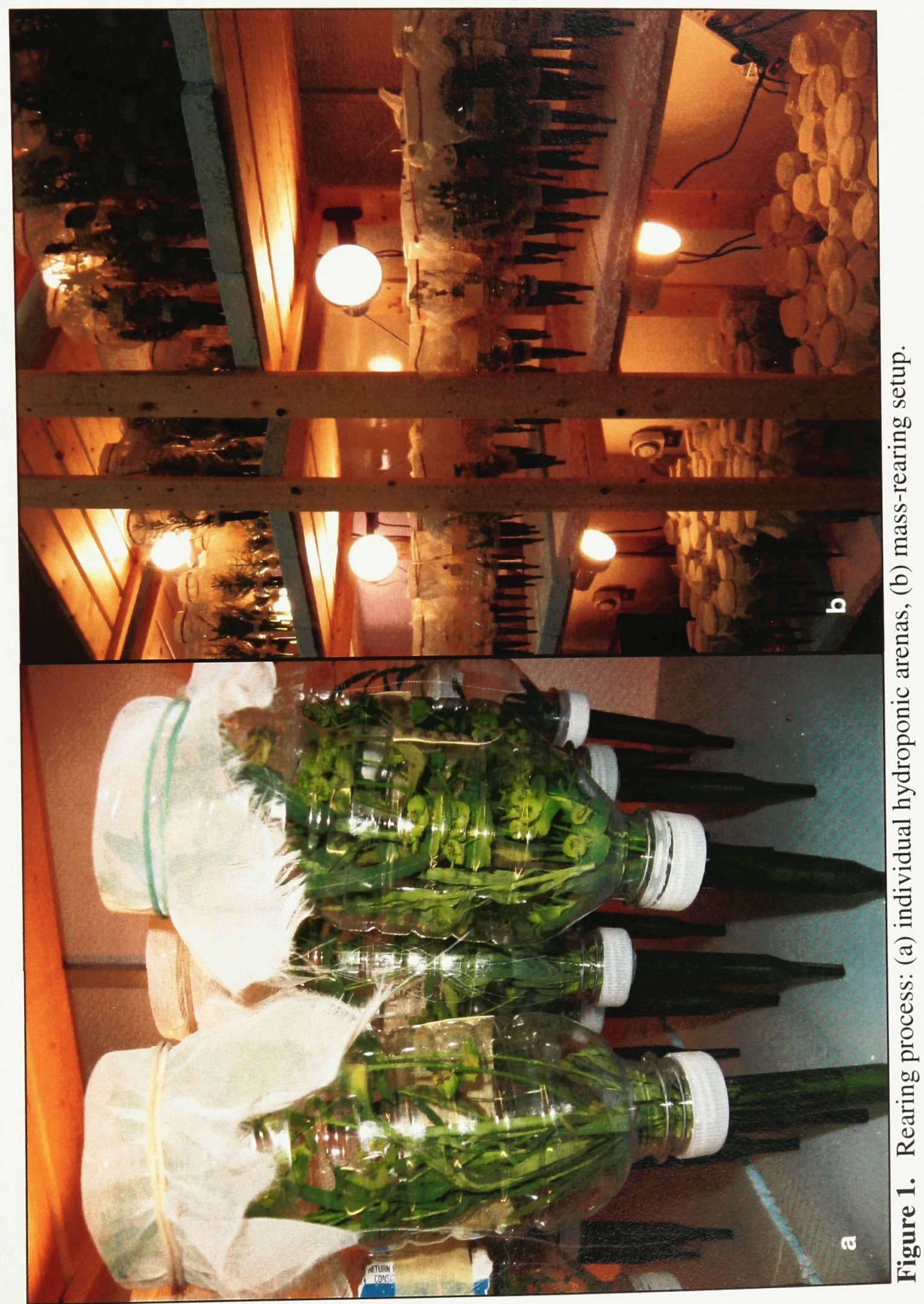




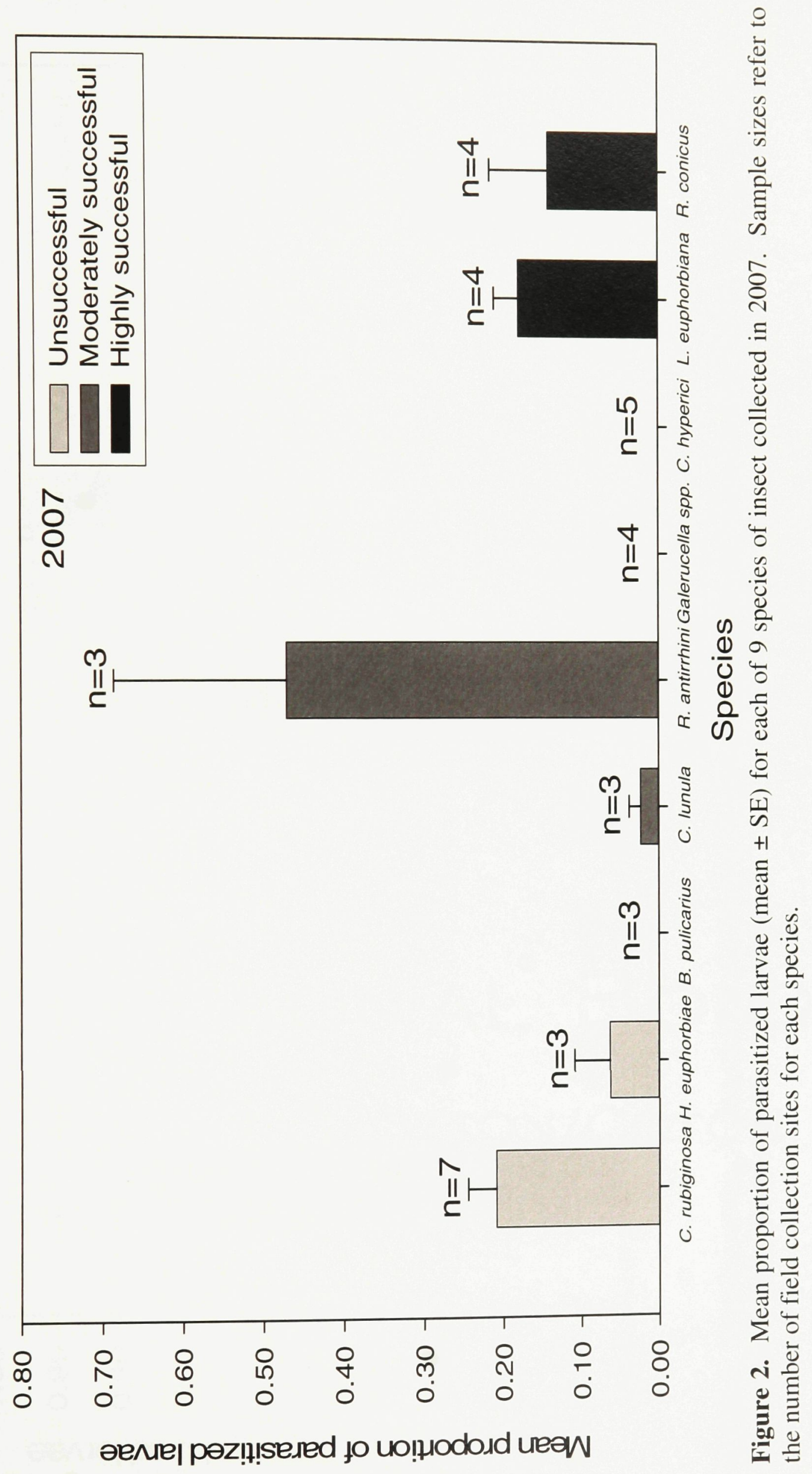




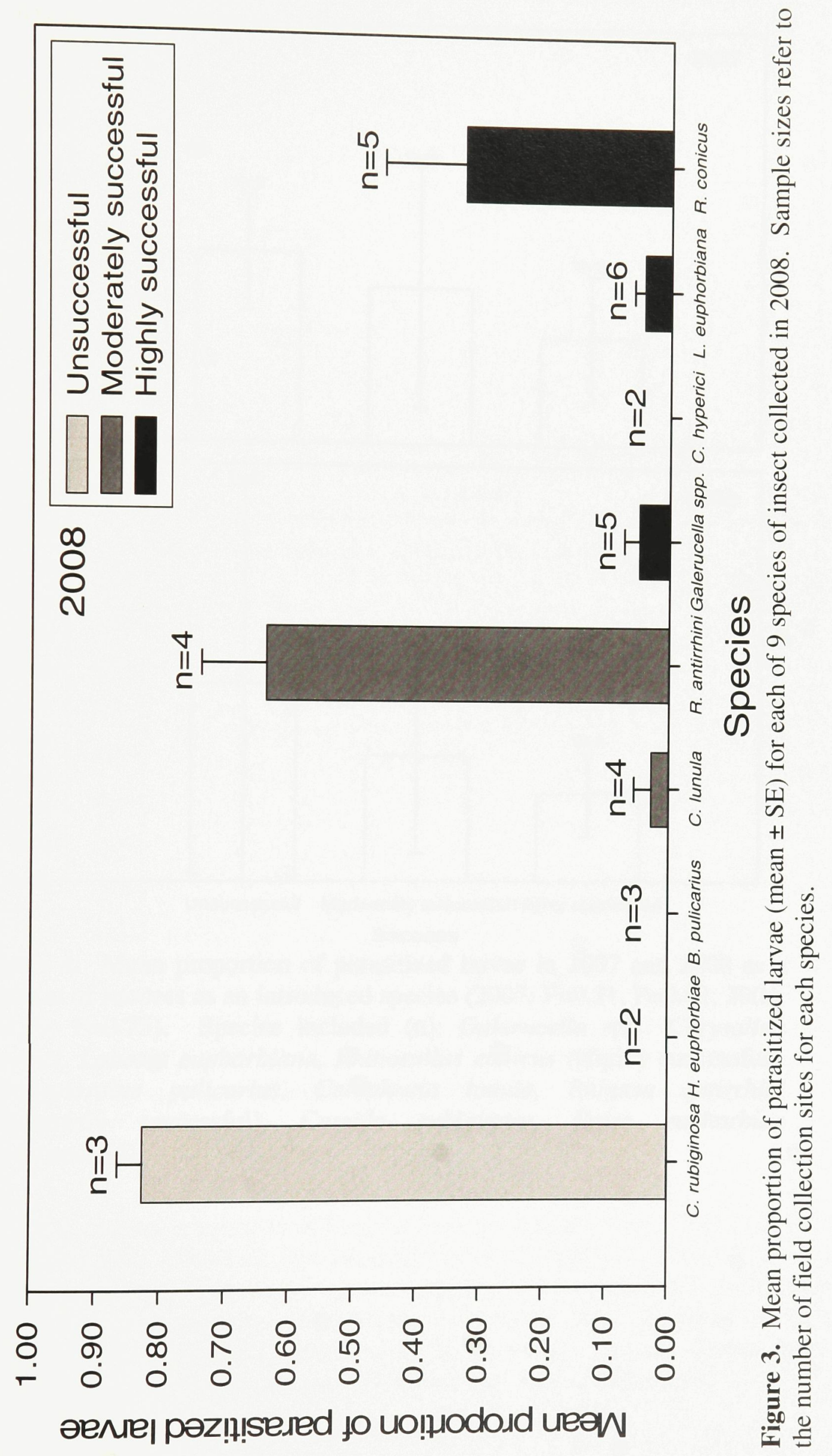




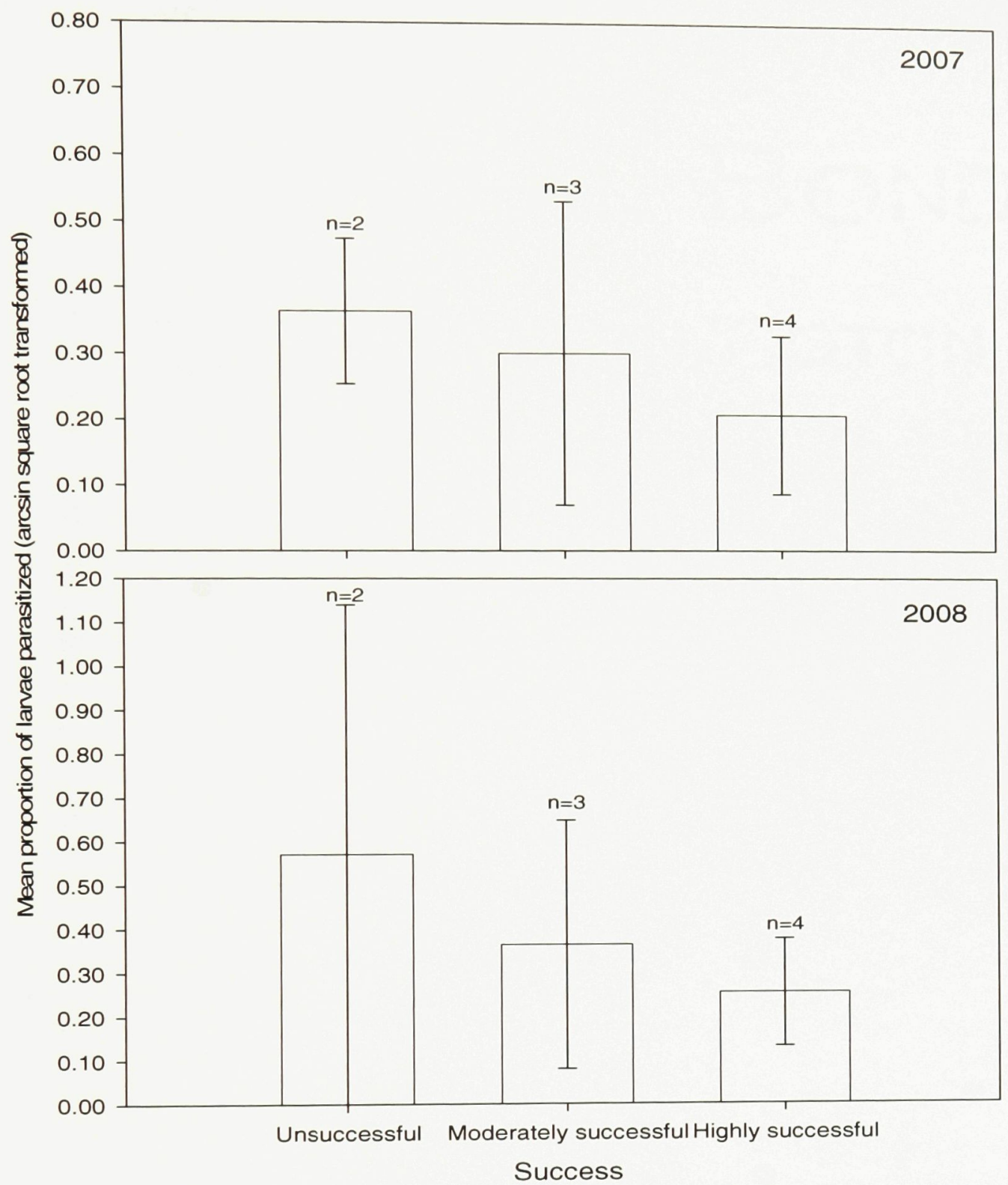

Figure 4. Mean proportion of parasitized larvae in 2007 and 2008 as a function of success as an introduced species (2007: $\mathrm{F}=0.21, \mathrm{P}=0.82 ; 2008$ : $\mathrm{F}=0.30, \mathrm{P}=0.75$ ). Species included (n): Galerucella spp., Chrysolina hyperici, Lobesia euphorbiana, Rhinocyllus conicus (Highly successful), Brachypterolus pulicarius, Calophasia lunula, Rhinusa antirrhini (Moderately successful), Cassida rubiginosa, Hyles euphorbiae (Unsuccessful). 


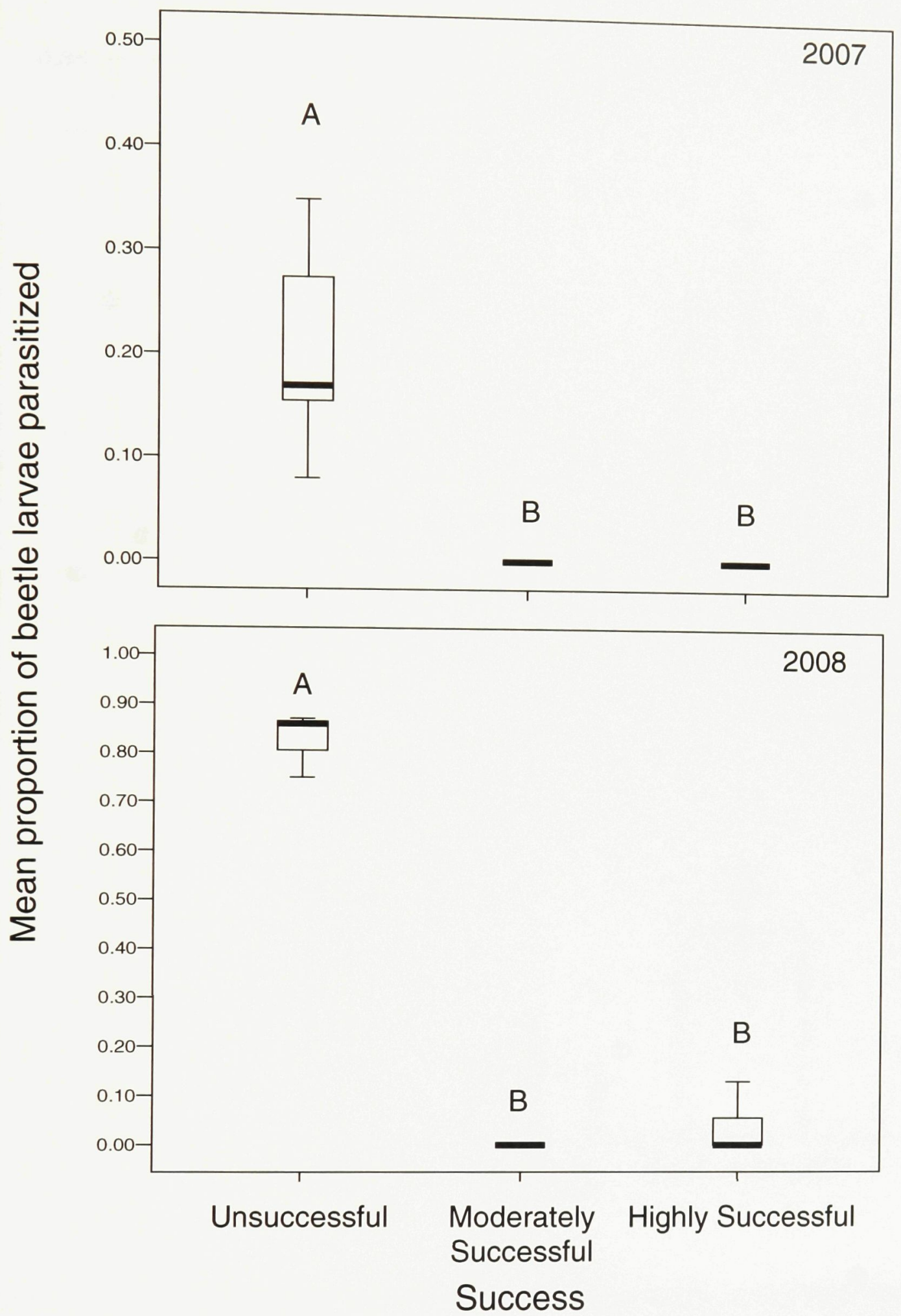

Figure 5. Mean proportion of beetle larvae parasitized across field sites (n) in 2007 and 2008 (2007: $\chi 2=16.82, \mathrm{P}=0.00 ; 2008: \chi 2=8.35, \mathrm{P}=0.02$ ). Beetle species included: Galerucella spp., Chrysolina hyperici (Highly successful; 2007: $\mathrm{n}=9 ; 2008: \mathrm{n}=7$ ), Brachypterolus pulicarius (Moderately successful; 2007 \& 2008: n=3), Cassida rubiginosa (Unsuccessful; 2007: $n=7 ; 2008: n=3$ ). Letters denote significantly different means according to Mann-Whitney pair-wise comparison. 


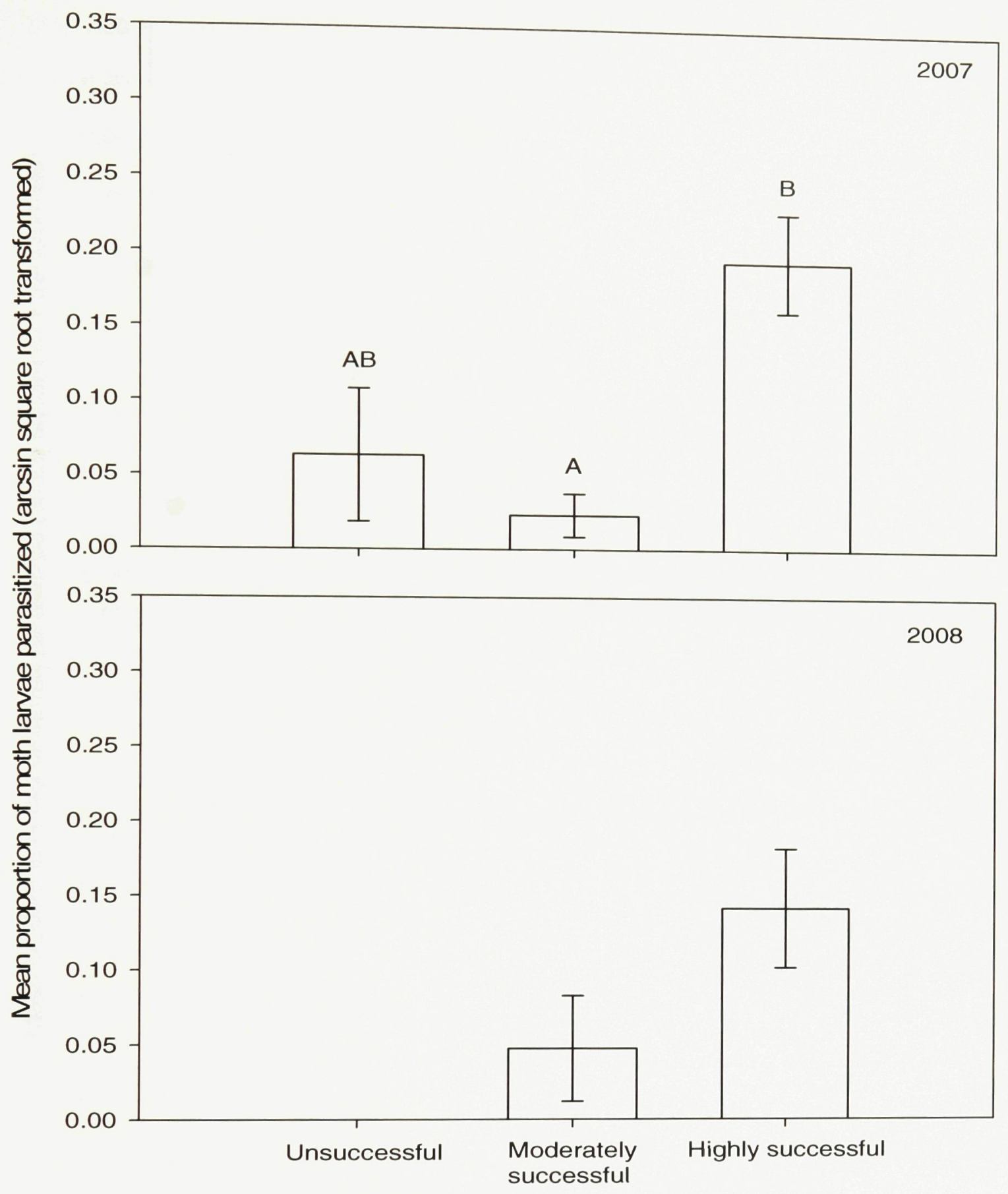

Success

Figure 6. Proportion of moth larvae parasitized (mean \pm SE) across field sites (n) in 2007 and 2008 (2007: $\mathrm{F}=6.09, \mathrm{P}=0.03 ; 2008: \mathrm{F}=1.07, \mathrm{P}=0.38$ ). Moth species included: Lobesia euphorbiana (Highly successful; 2007: $n=4 ; 2008: n=6$ ), Calophasia lunula (Moderately successful; 2007: n=3; 2008: n=4), Hyles euphorbiae (Unsuccessful; 2007: $\mathrm{n}=3 ; 2008: \mathrm{n}=2$ ). Letters denote significantly different means (Tukey's HSD). 


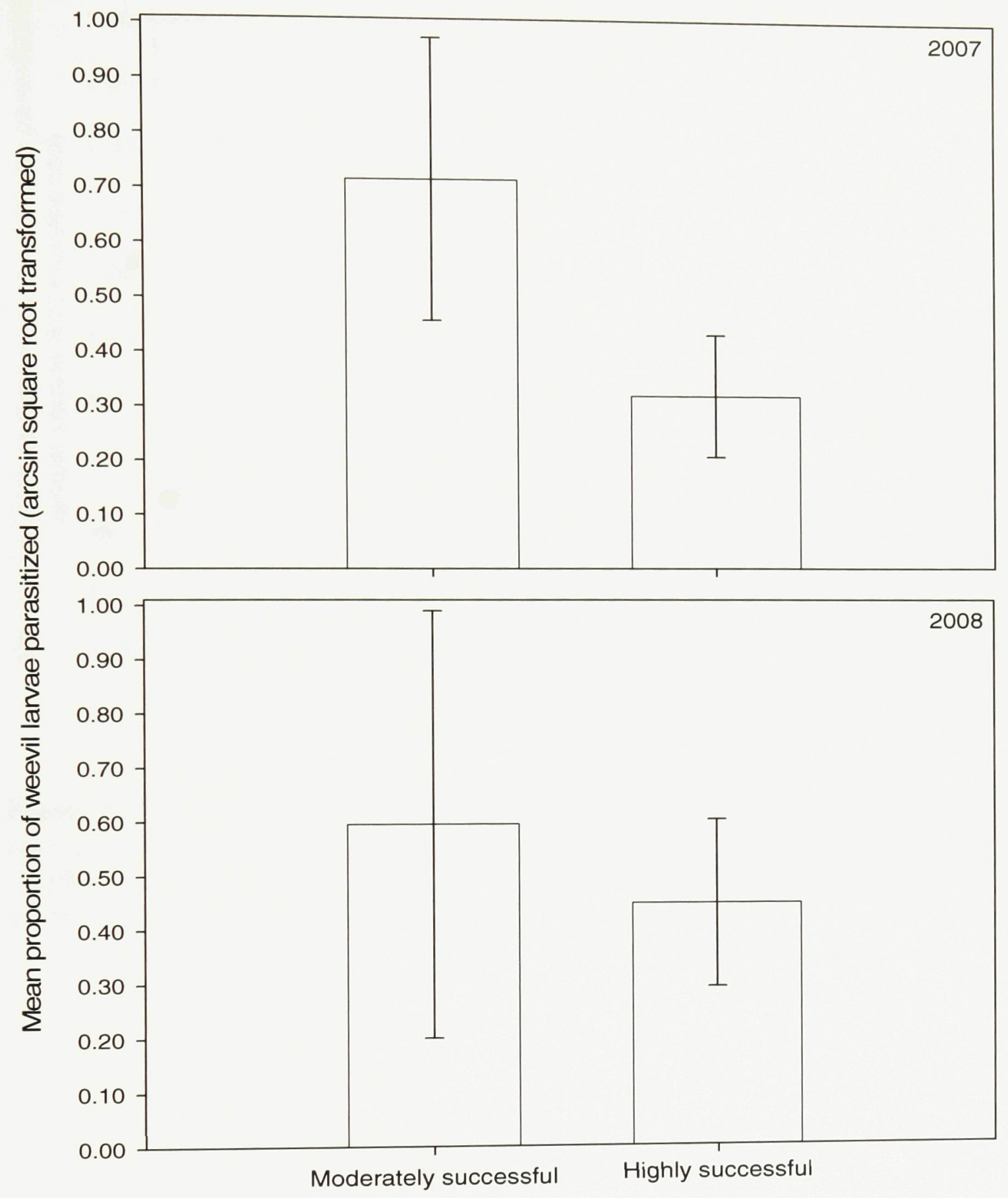

Success

Figure 7. Proportion of weevil larvae parasitized (mean $\pm S E$ ) across field sites $(n)$ in 2007 and 2008 (2007: $\mathrm{t}=-1.55, \mathrm{P}=0.18 ; 2008: \mathrm{t}=-1.96, \mathrm{P}=0.09)$. Weevil species included: Rhinocyllus conicus (Highly successful; 2007: $\mathrm{n}=4 ; 2008: \mathrm{n}=5$ ), Rhinusa antirrhini (Moderately successful; 2007: $n=3 ; 2008: n=4$ ). 


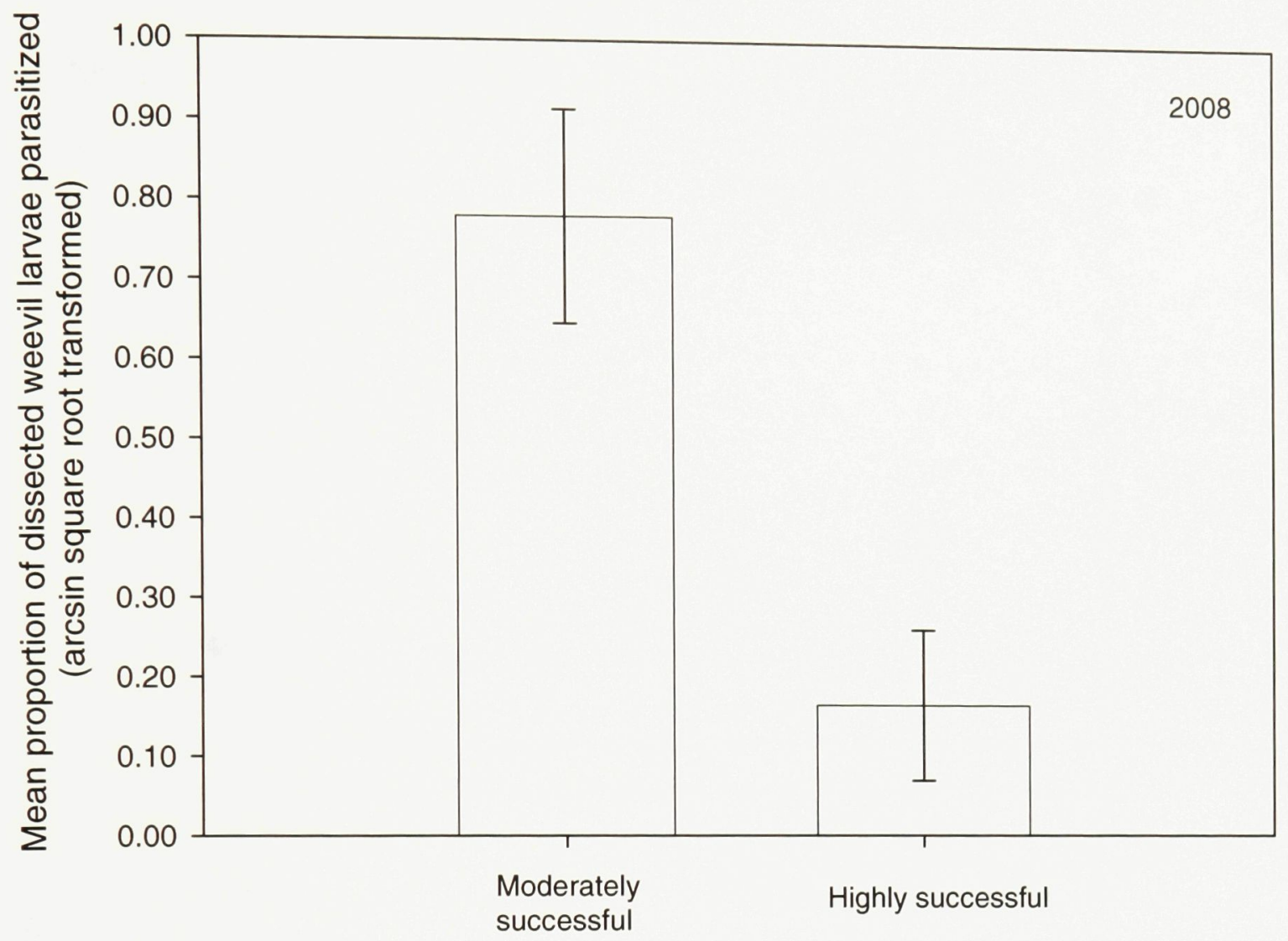

Success

Figure 8. Proportion of dissected weevil larvae parasitized (mean $\pm \mathrm{SE}$ ) across field sites $(\mathrm{n})$ in 2008 ( $\mathrm{t}=-3.71, \mathrm{P}=0.01)$. Weevil species included: Rhinocyllus conicus (Highly successful; 2007: $\mathrm{n}=4$; 2008: $\mathrm{n}=5$ ), Rhinusa antirrhini (Moderately successful; 2007: $n=3 ; 2008: n=4)$. 


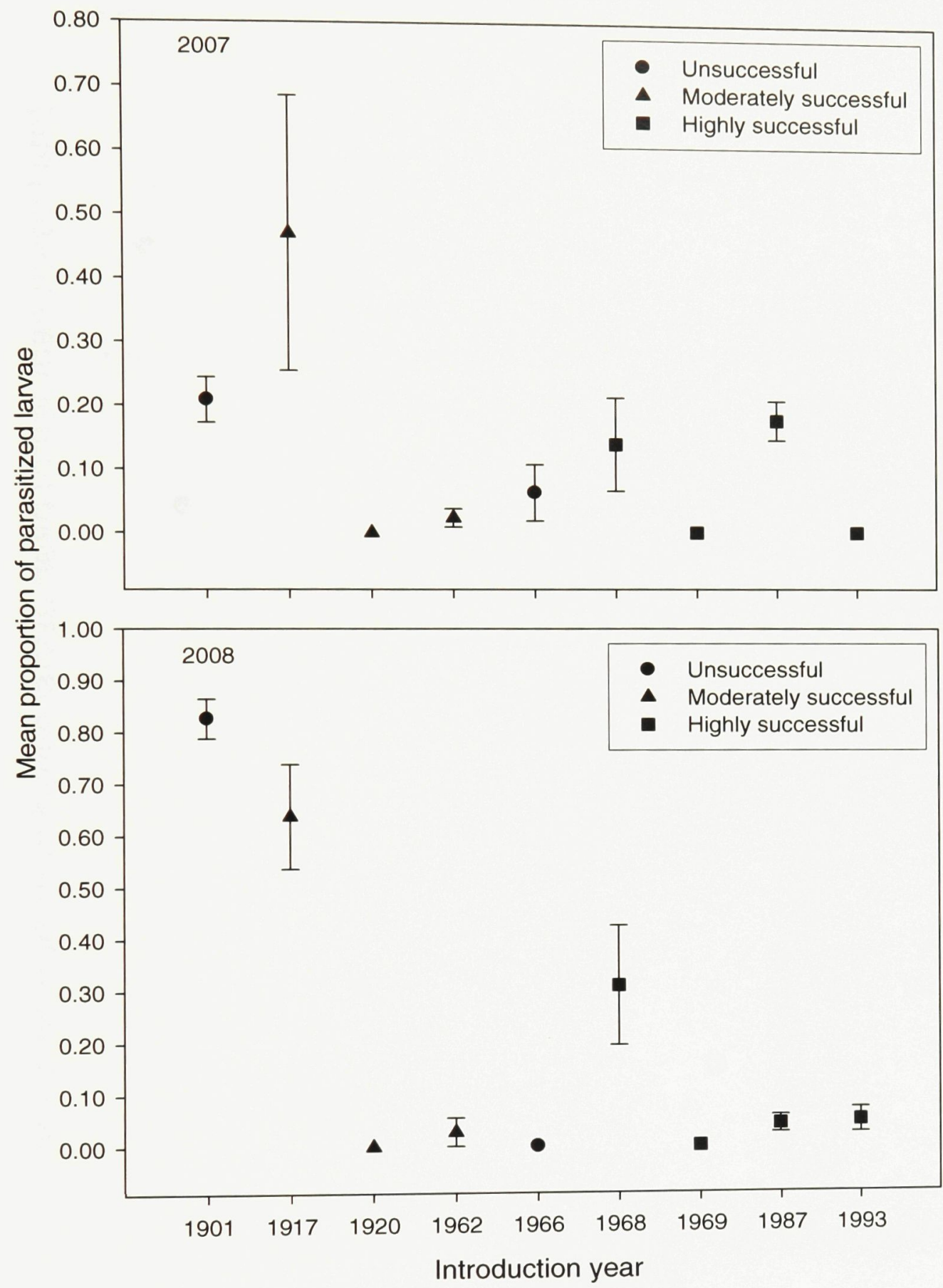

Figure 9. Proportion of larvae parasitized as a function of introduction year (2007: Spearman's Rho=-0.44, P=0.01, $\mathrm{n}=36$; 2008: Spearman's $\mathrm{Rho}=-0.39, \mathrm{P}=0.02, \mathrm{n}=34)$. Species included: Galerucella spp., Chrysolina hyperici, Lobesia euphorbiana, Rhinocyllus conicus (Highly successful), Brachypterolus pulicarius, Rhinusa antirrhini, Calophasia lunula (Moderately successful), Cassida rubiginosa, Hyles euphorbiae (Unsuccessful). 


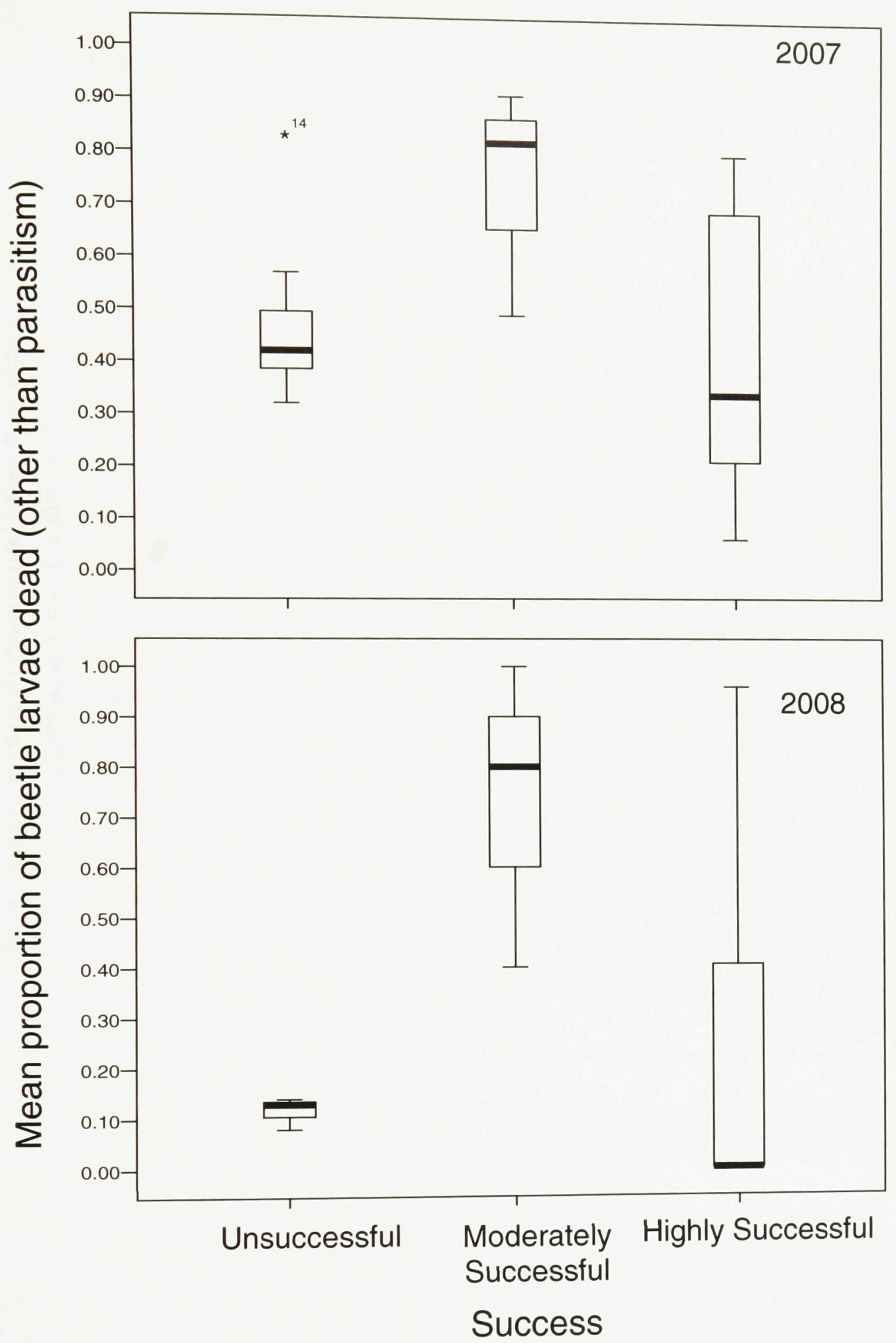

Figure 10. Proportion of beetle larvae dead (causes other than parasitism) across field sites (n) in 2007 and 2008 (2007: $\chi 2=3.95, P=0.14 ; 2008: \chi 2=4.02, P=0.13$ ). Beetle species included: Galerucella calmariensis, G. pusilla, Chrysolina hyperici (Highly successful; 2007: n=9; 2008: n=7), Brachypterolus pulicarius (Moderately successful; 2007 \& 2008: $n=3$ ), Cassida rubiginosa (Unsuccessful; 2007: n=7; 2008: $\mathrm{n}=3$ ). Letters denote significantly different means according to Mann-Whitney pairwise comparison. 


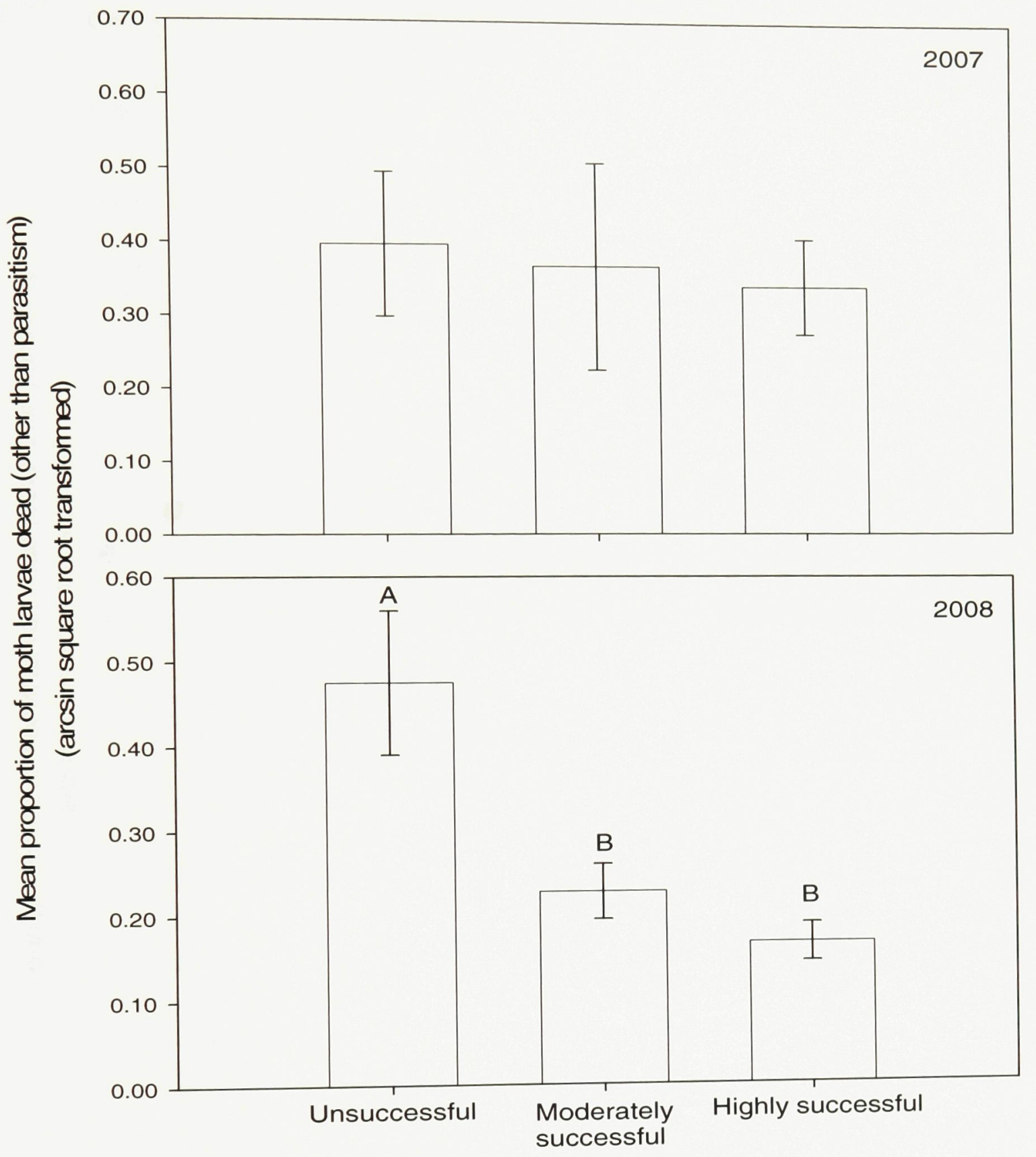

Success

Figure 11. Proportion of moth larvae dead (causes other than parasitism) (mean \pm SE) across field sites (n) in 2007 and 2008 (2007: $F=0.09, P=0.92 ; 2008: F=10.08$, $\mathrm{P}=0.01$ ). Moth species included: Lobesia euphorbiana (Highly successful; 2007: $\mathrm{n}=4$; 2008: n=6), Calophasia lunula (Moderately successful; 2007: n=3; 2008: n=4), Hyles euphorbiae (Unsuccessful; 2007: $n=3 ; 2008$ : $n=2$ ). Letters denote significantly different means (Tukey's HSD). 


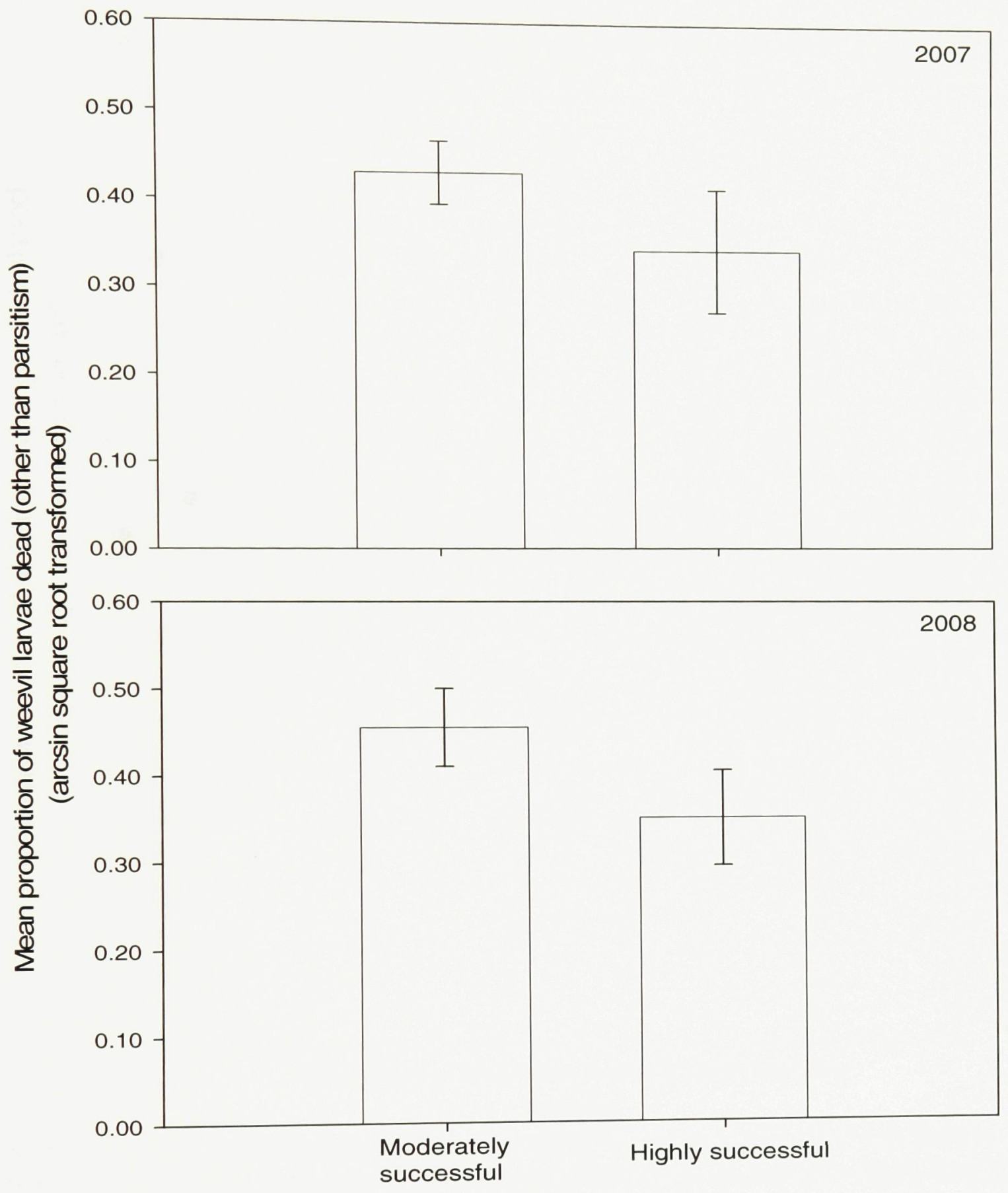

Success

Figure 12. Proportion of weevil larvae dead (causes other than parasitism) (mean \pm SE) across field sites (n) in 2007 and 2008 (2007: $t=-1.05, P=0.34 ; 2008: t=3.14$, $\mathrm{P}=0.02$ ). Weevil species included: Rhinocyllus conicus (Highly successful; 2007: n=4; 2008: n=5), Rhinusa antirrhini (Moderately successful; 2007: $n=3 ; 2008: n=4$ ). 


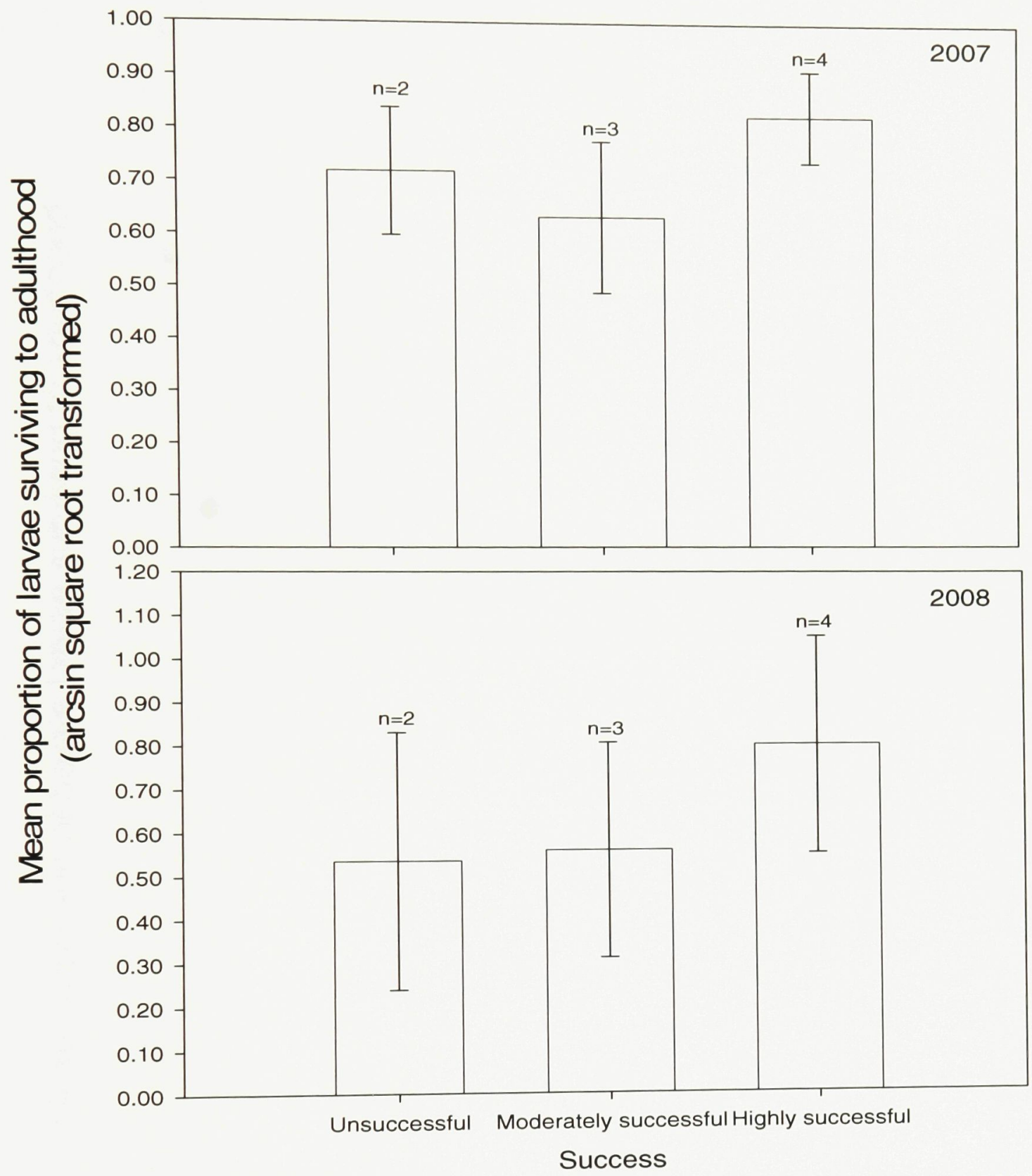

Figure 13. Mean proportion of larvae surviving to adulthood in 2007 and 2008 as a function of success as an introduced species $(2007: \mathrm{F}=0.79, \mathrm{P}=0.50 ; 2008: \mathrm{F}=0.33$, $\mathrm{P}=0.73$ ). Species included (n): Galerucella spp., Chrysolina hyperici, Lobesia euphorbiana, Rhinocyllus conicus (Highly successful), Brachypterolus pulicarius, Calophasia lunula, Rhinusa antirrhini (Moderately successful), Cassida rubiginosa, Hyles euphorbiae (Unsuccessful). 


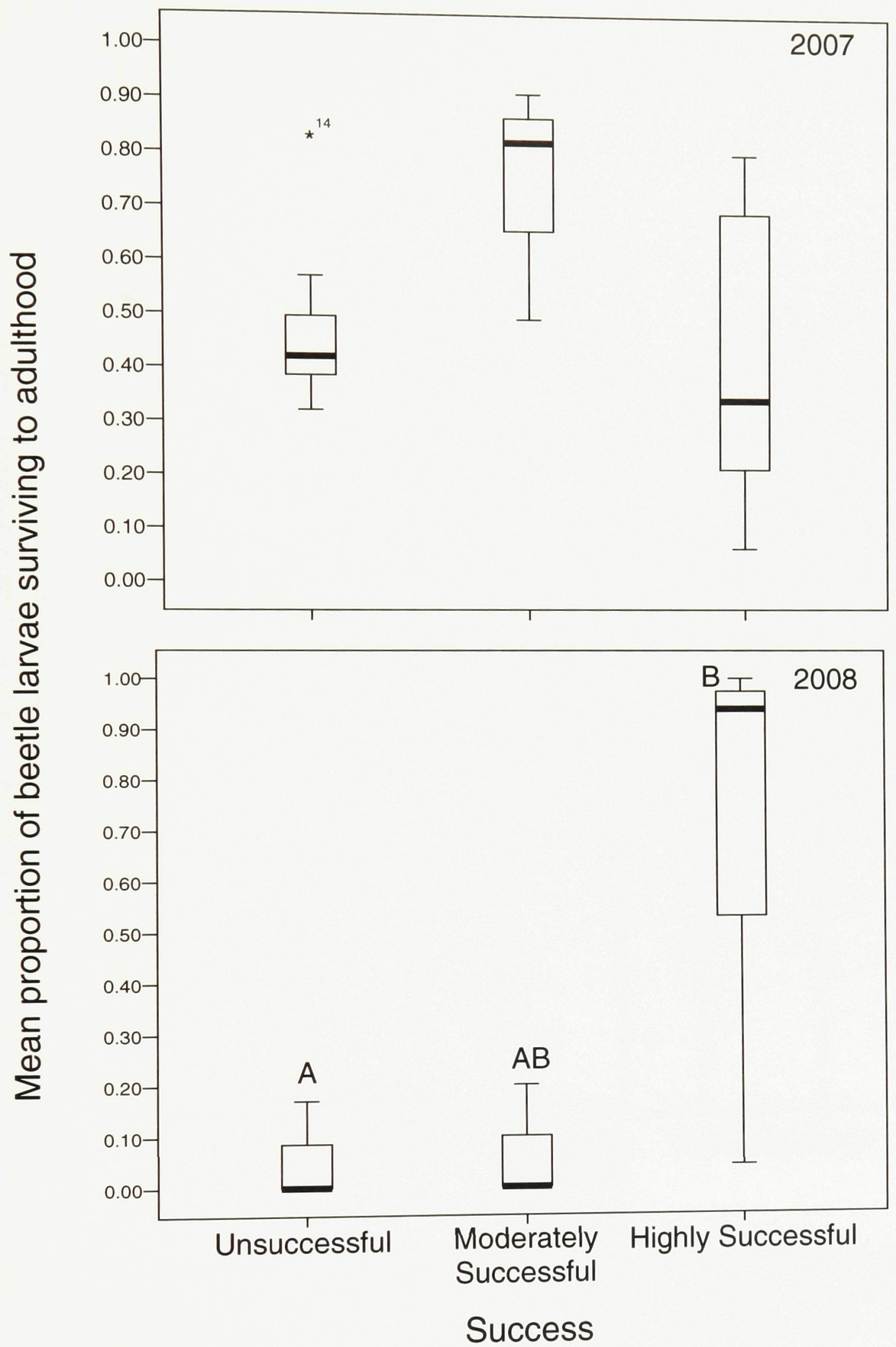

Figure 14. Proportion of beetle larvae surviving to adulthood across field sites $(\mathrm{n})$ in 2007 and 2008 (2007: $\chi 2=4.62, \mathrm{P}=0.09 ; 2008: \chi 2=6.86, \mathrm{P}=0.03$ ). Beetle species included: Galerucella spp., Chrysolina hyperici (Highly successful; 2007: n=9; 2008: $\mathrm{n}=7$ ), Brachypterolus pulicarius (Moderately successful; 2007 \& 2008: n=3), Cassida rubiginosa (Unsuccessful; 2007: $n=7 ; 2008$ : $n=3$ ). Letters denote significantly different means according to Mann-Whitney pair-wise comparison. 


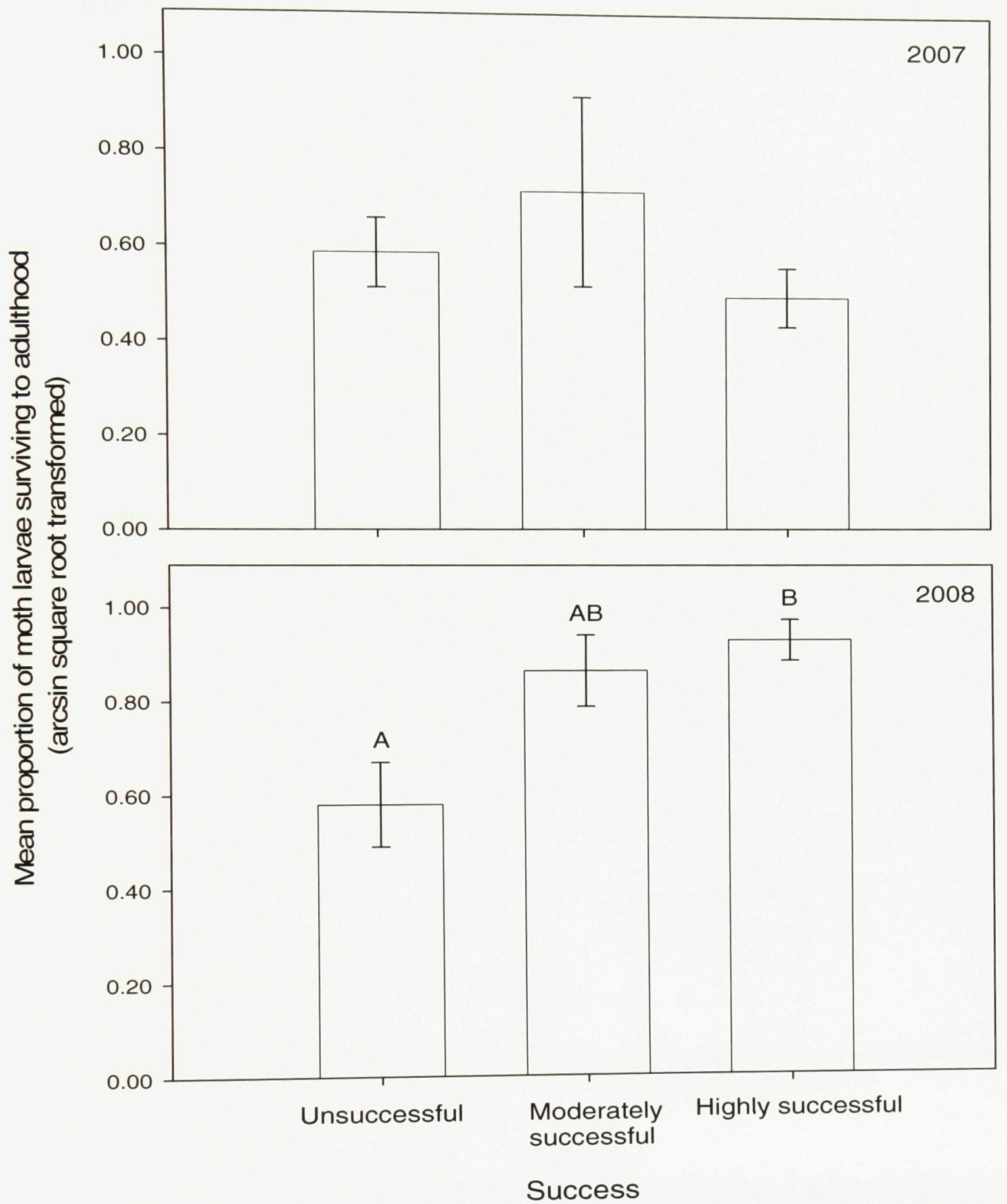

Figure 15. Proportion of moth larvae surviving to adulthood (mean $\pm \mathrm{SE}$ ) across field sites (n) in 2007 and 2008 (2007: $\mathrm{F}=0.86, \mathrm{P}=0.46 ; 2008: \mathrm{F}=6.46, \mathrm{P}=0.02$ ). Moth species included: Lobesia euphorbiana (Highly successful; 2007: $\mathrm{n}=4$; 2008: $\mathrm{n}=6$ ), Calophasia lunula (Moderately successful; 2007: $\mathrm{n}=3$; 2008: $\mathrm{n}=4$ ), Hyles euphorbiae (Unsuccessful; 2007: $n=3 ; 2008$ : $n=2$ ). Letters denote significantly different means (Tukey's HSD). 


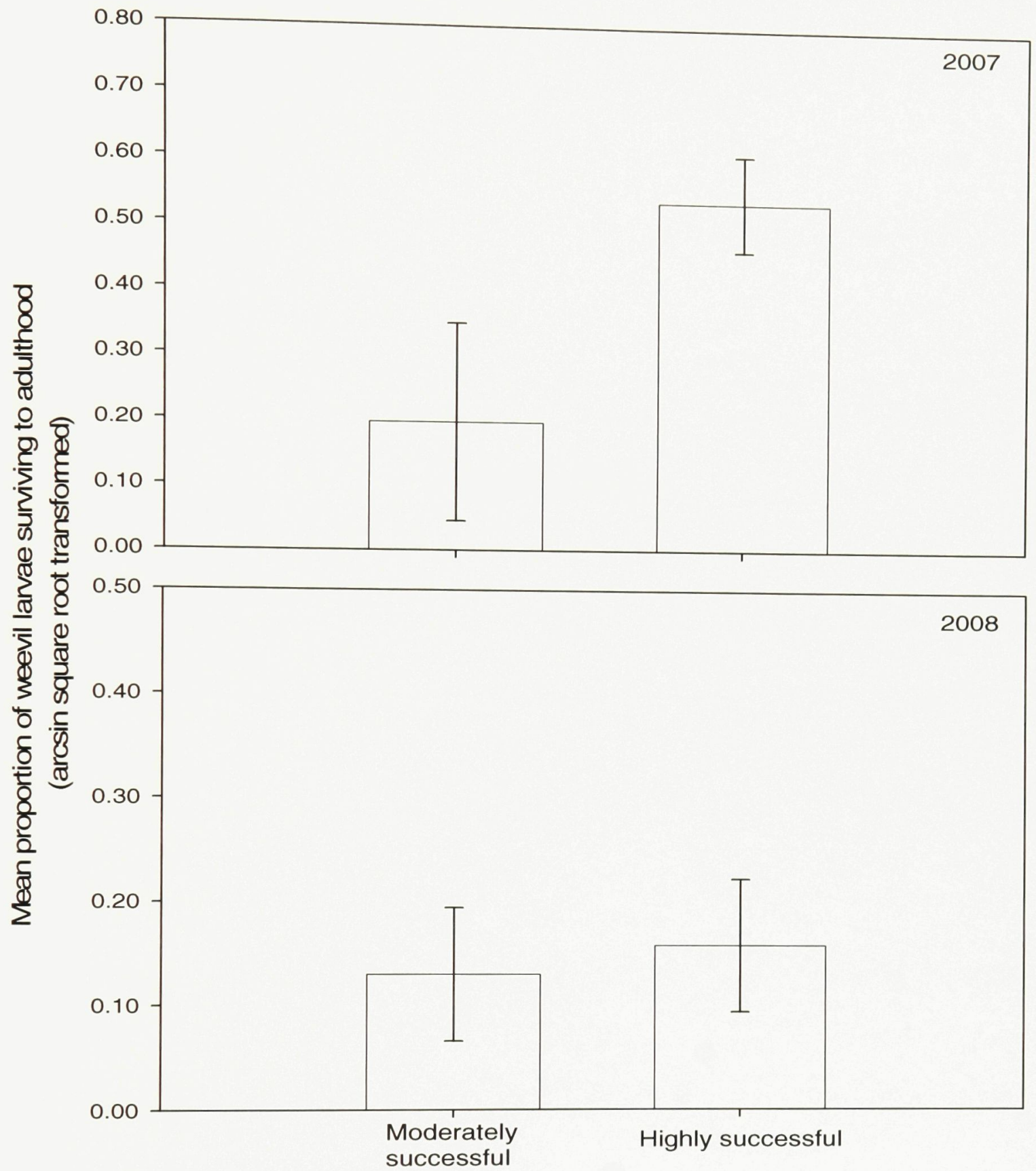

\section{Success}

Figure 16. Proportion of weevil larvae surviving to adulthood (mean \pm SE) across field sites in 2007 and 2008 (2007: $\mathrm{t}=2.26, \mathrm{P}=0.07 ; 2008 \mathrm{t}=0.54, \mathrm{P}=0.61)$. Weevil species included: Rhinocyllus conicus (Highly successful; 2007: $\mathrm{n}=4 ; 2008: \mathrm{n}=5$ ), Rhinusa antirrhini (Moderately successful; 2007: $\mathrm{n}=3$; 2008: $\mathrm{n}=4$ ). 
Appendices 


\section{Appendix A. Larval collection data}

Table 2. Total individuals collected, parasitized and reared to adulthood for nine species of insect from field sites in 2007 and 2008.

\begin{tabular}{|c|c|c|c|c|c|}
\hline Success & $\begin{array}{l}\text { Field } \\
\text { site } \\
\end{array}$ & Genus species & $\begin{array}{c}\text { Total } \\
\text { individuals } \\
\end{array}$ & Parasitized & Adults \\
\hline \multirow{17}{*}{$\begin{array}{l}\text { Highly } \\
\text { successful }\end{array}$} & 1 & Galerucella spp. & 52 & 0 & 41 \\
\hline & 2 & Galerucella spp. & 34 & 0 & 31 \\
\hline & 3 & Galerucella spp. & 75 & 0 & 54 \\
\hline & 4 & Galerucella spp. & 92 & 0 & 62 \\
\hline & 1 & Chrysolina hyperici & 10 & 0 & 2 \\
\hline & 2 & Chrysolina hyperici & 32 & 0 & 9 \\
\hline & 3 & Chrysolina hyperici & 43 & 0 & 14 \\
\hline & 4 & Chrysolina hyperici & 11 & 0 & 9 \\
\hline & 5 & Chrysolina hyperici & 35 & 0 & 11 \\
\hline & 1 & Rhinocyllus conicus & 53 & 6 & 34 \\
\hline & 2 & Rhinocyllus conicus & 19 & 0 & 7 \\
\hline & 3 & Rhinocyllus conicus & 47 & 8 & 27 \\
\hline & 4 & Rhinocyllus conicus & 73 & 18 & 32 \\
\hline & 1 & Lobesia euphorbiana & 94 & 15 & 57 \\
\hline & 2 & Lobesia euphorbiana & 127 & 24 & 63 \\
\hline & 3 & Lobesia euphorbiana & 65 & 9 & 22 \\
\hline & 4 & Lobesia euphorbiana & 38 & 11 & 17 \\
\hline \multirow{9}{*}{$\begin{array}{l}\text { Moderately } \\
\text { successful }\end{array}$} & 1 & Brachypterolus pulicarius & 11 & 0 & 2 \\
\hline & 2 & Brachypterolus pulicarius & 11 & 0 & 1 \\
\hline & 3 & Brachypterolus pulicarius & 51 & 0 & 25 \\
\hline & 1 & Rhinusa antirrhini & 27 & 18 & 1 \\
\hline & 2 & Rhinusa antirrhini & 20 & 14 & 1 \\
\hline & 3 & Rhinusa antirrhini & 25 & 1 & 12 \\
\hline & 1 & Calophasia lunula & 21 & 1 & 8 \\
\hline & 2 & Calophasia lunula & 118 & 2 & 74 \\
\hline & 3 & Calophasia lunula & 25 & 0 & 22 \\
\hline \multirow[t]{6}{*}{ Unsuccessful } & 1 & Cassida rubiginosa & 77 & 27 & 18 \\
\hline & 2 & Cassida rubiginosa & 6 & 1 & 0 \\
\hline & 3 & Cassida rubiginosa & 50 & 8 & 26 \\
\hline & 4 & Cassida rubiginosa & 13 & 1 & 7 \\
\hline & 5 & Cassida rubiginosa & 26 & 4 & 11 \\
\hline & 6 & Cassida rubiginosa & 62 & 18 & 20 \\
\hline
\end{tabular}




\begin{tabular}{clccc}
7 & Cassida rubiginosa & 23 & 6 & 4 \\
\hline 1 & Hyles euphorbiae & 26 & 4 & 16 \\
2 & Hyles euphorbiae & 56 & 2 & 24 \\
3 & Hyles euphorbiae & 26 & 0 & 16 \\
\hline
\end{tabular}

2008

\begin{tabular}{|c|c|c|c|c|c|}
\hline Success & $\begin{array}{l}\text { Field } \\
\text { site } \\
\end{array}$ & Genus species & $\begin{array}{c}\text { Total } \\
\text { individuals } \\
\end{array}$ & Parasitized & Adults \\
\hline \multirow{18}{*}{$\begin{array}{l}\text { Highly } \\
\text { successful }\end{array}$} & 1 & Galerucella spp. & 21 & 1 & 20 \\
\hline & 2 & Galerucella spp. & 18 & 0 & 18 \\
\hline & 3 & Galerucella spp. & 10 & 0 & 10 \\
\hline & 4 & Galerucella spp. & 15 & 2 & 13 \\
\hline & 5 & Galerucella spp. & 16 & 1 & 15 \\
\hline & 1 & Chrysolina hyperici & 26 & 0 & 5 \\
\hline & 2 & Chrysolina hyperici & 25 & 0 & 1 \\
\hline & 1 & Rhinocyllus conicus & 22 & 9 & 1 \\
\hline & 2 & Rhinocyllus conicus & 10 & 3 & 1 \\
\hline & 3 & Rhinocyllus conicus & 25 & 4 & 3 \\
\hline & 4 & Rhinocyllus conicus & 15 & 0 & 6 \\
\hline & 5 & Rhinocyllus conicus & 28 & 19 & 3 \\
\hline & 1 & Lobesia euphorbiana & 64 & 4 & 48 \\
\hline & 2 & Lobesia euphorbiana & 53 & 0 & 43 \\
\hline & 3 & Lobesia euphorbiana & 47 & 4 & 38 \\
\hline & 4 & Lobesia euphorbiana & 52 & 4 & 41 \\
\hline & 5 & Lobesia euphorbiana & 51 & 1 & 46 \\
\hline & 6 & Lobesia euphorbiana & 54 & 0 & 39 \\
\hline \multirow{11}{*}{$\begin{array}{l}\text { Moderately } \\
\text { successful }\end{array}$} & 1 & Brachypterolus pulicarius & 10 & 0 & 2 \\
\hline & 2 & Brachypterolus pulicarius & 19 & 0 & 0 \\
\hline & 3 & Brachypterolus pulicarius & 10 & 0 & 0 \\
\hline & 1 & Rhinusa antirrhini & 22 & 13 & 6 \\
\hline & 2 & Rhinusa antirrhini & 20 & 17 & 0 \\
\hline & 3 & Rhinusa antirrhini & 22 & 16 & 1 \\
\hline & 4 & Rhinusa antirrhini & 16 & 6 & 3 \\
\hline & 1 & Calophasia lunula & 32 & 0 & 28 \\
\hline & 2 & Calophasia lunula & 31 & 0 & 23 \\
\hline & 3 & Calophasia lunula & 28 & 0 & 21 \\
\hline & 4 & Calophasia lunula & 45 & 5 & 29 \\
\hline \multirow[t]{2}{*}{ Unsuccessful } & 1 & Cassida rubiginosa & 23 & 20 & 0 \\
\hline & 2 & Cassida rubiginosa & 14 & 12 & 0 \\
\hline
\end{tabular}




\begin{tabular}{ccccc}
3 & Cassida rubiginosa & 12 & 9 & 2 \\
\hline 1 & Hyles euphorbiae & 34 & 0 & 21 \\
2 & Hyles euphorbiae & 17 & 0 & 8 \\
\hline
\end{tabular}

